\title{
Bacterial responses to temperature and substrate concentration during the Newfoundland spring bloom
}

\author{
Lawrence R. Pomeroy ${ }^{1,2}{ }^{2}$, William J. Wiebe ${ }^{2,3}$, Don Deibel ${ }^{4}$, Raymond J. Thompson ${ }^{4}$, \\ G. T. Rowe ${ }^{5}$, J. Dean Pakulski ${ }^{1{ }^{*}}$ \\ ${ }^{1}$ Department of Zoology, University of Georgia, Athens, Georgia 30602, USA \\ ${ }^{2}$ Institute of Ecology, University of Georgia, Athens, Georgia 30602, USA \\ ${ }^{3}$ Department of Microbiology, University of Georgia, Georgia 30602, USA \\ ${ }^{4}$ Ocean Sciences Centre, Memorial University of Newfoundland, St. John's, Newioundland, Canada A1C 5S7 \\ ${ }^{5}$ Department of Oceanography, Texas A \& M University, College Station, Texas 77984-3146, USA
}

\begin{abstract}
We postulate that microbial metabolism and production in cold waters are limited by the ability of bacteria to transport and/or assimilate substrates at the low concentrations usually present. We measured rates of microbial activity in the water column and benthos in Conception Bay, Newfoundland and adjacent coastal waters, during 3 spring blooms. Chlorophyll abundance and distribution, photosynthesis, benthic respiratory rate and remineralization, bacterioplankton abundance, and production of bacterial biomass were measured in the water column, and the respiratory rate of benthic sediments was measured in situ by a free vehicle containing bell jars equipped with oxygen electrodes and syringe samplers. During 3 spring seasons, bacterioplankton numbers during the spiing phytoplankton bloom exceeded $5 \times 10^{5} \mathrm{ml}^{-1}$ only $15 \%$ of the time. These numbers rank at the lower end of the range of bacterial numbers for the world's ocean. Bacterial productivity measured by 3 methods suggested average generation times of 30 to $86 \mathrm{~d}$, although some samples in the chlorophyll maximum layer showed short generation times. Bacterial production and respiration, averaged over the entire water column, plus benthic aerobic respiration and denitrification, accounted for $3 \%$ of primary production during the early bloom and $28 \%$ of primary production during the late bloom. The difference between the early and late bloom is related to observed changes in primary production, not to increased microbial activity. Unless bacterial assimilation efficiency was very low, much less than half of the organic production of the spring diatom bloom was used by microbial processes during the early, highly productive phase of the bloom, while somewhat more than half of organic production was used in the short term during the later, less productive phase of the spring bloom. To test the hypothesis that bacteria require higher substrate concentrations at low temperature, water samples were amended with glucose and proteose-peptone and incubated for $2 \mathrm{wk}$ at -1 to $+15^{\circ} \mathrm{C}$. Respiratory rate, measured at intervals of 1 to $2 \mathrm{~d}$, increased with increasing temperature and/or substrate concentration. Analysis of variance showed significant effects of temperature and substrate in all cases. In 3 of 4 experiments there were also significant effects due to the interaction of temperature and substrate
\end{abstract}

\section{INTRODUCTION}

Heterotrophic microbial processes, as currently measured, commonly account for more than half of the total flux of energy and materials in marine food webs (reviews by Azam et al. 1983, Williams 1984, Pomeroy \& Wiebe 1988). However, several investigators have suggested that the microbial loop is not always a

\footnotetext{
- Present address: Marine Science Institute, University of Texas at Austin, Port Aransas, Texas 78373, USA
}

dominant part of marine food webs, particularly in north-temperate or subpolar spring diatom blooms (Schnack et al. 1985, Pomeroy \& Deibel 1986, Nielsen \& Richardson 1989), some ice-algae communities (Smith et al. 1989), and the water beneath seasonal sea ice (Pomeroy et al. 1990). In contrast to this, frequent reports of high rates of microbial metabolism in high latitudes and cold temperate waters (e.g. Morita et al. 1977. Hodson et al. 1981) have led others to suggest that there is nothing fundamentally different about microbial metabolism in cold water (Li \& Dickie 1988, 
Bird \& Karl 1988). No resolution of these seemingly conflicting views has emerged in recent literature.

Variation in temperature alone does not appear to explain the wide range of microbial rate processes reported from cold water. Smetacek \& Pollehne (1986) discussed various factors that could account for the variability, suggesting a positive feedback relationship between copepod grazing and the stimulation of microbial loop activity through release of labile substrates. A number of observations suggest, however, that stimulation of microbial loop activity in the cold requires higher concentrations of substrate than it does in temperate waters. This implies that activity of the microbial loop is controlled by the interaction of 2 factors, temperature and substrate concentration. We have gathered additional observations on natural microbial populations which indicate that at temperatures near the freezing point of sea ice the concentration of substrates available to bacteria often is less than that necessary for the development and function of microbial food webs. Recognition of this constraint may help us predict situations in which inhibition of bacterial production would occur in cold water and to understand some of the mechanisms responsible for it. Our observations are from the spring bloom in coastal Newfoundland waters in 1986, 1988, and 1990. The presence of the Labrador Current makes the Newfoundland fjords and continental shelf good sites to investigate processes in cold water.

\section{METHODS}

Study sites. All sampling in 1986 was done in Conception Bay, Newfoundland, a fjord over $300 \mathrm{~m}$ in depth, opening to the Atlantic Ocean (Fig. 1). The eastern coast of Newfoundland is dominated by the Labrador Current, which enters Conception Bay as a tongue of very cold water $\left(-1.5\right.$ to $\left.-1{ }^{\circ} \mathrm{C}\right)$ at a sill depth of $170 \mathrm{~m}$ (Leggett et al. 1984, Taggart \& Leggett 1987). Below $100 \mathrm{~m}$, water temperature is between 0 and $-1.5^{\circ} \mathrm{C}$ throughout the year. CTD casts during the 1986 spring bloom showed rapid changes in the depth of the cold middle layer of water that is derived from the Labrador Current, especially when southwesterly winds diplaced surface water offshore, promoting intrusion of Labrador Current water. Below sill depth, the bottom water appeared to be less rapidly exchanged. A regular study site, $270 \mathrm{~m}$ in depth, was $64 \mathrm{~km}$ from the mouth of the bay, $4.3 \mathrm{~km}$ SE of Brigus lighthouse $\left(47^{\circ} 32.2^{\prime} \mathrm{N}, 53^{\circ} 07.9^{\prime} \mathrm{W}\right)$. All sampling in 1986 was done from the Department of Fisheries and Oceans vessel 'Shamook' and Memorial University's vessel 'Karl and Jackie II'. In 1988 and 1990, in addition to observations at the Brigus site aboard 'Shamook' and 'Karl and Jackie II', we sampled throughout Conception Bay and in the Avalon Channel on the continental shelf between Newfoundland and the Grand Banks aboard C.S.S. 'Baffin'.

Water samples. Water samples were collected in cleaned Niskin samplers containing silicone elastic closures. A Seabird CTD with Sea Tech fluorometer was cast before water sampling, so samples could be collected either in or out of layers occupied by the diatom bloom, the mixed layer, the Labrador Current water, or the bottom water. During the early and middle parts of the bloom, the chlorophyll maximum was generally centered in the upper mixed layer, 10 to $30 \mathrm{~m}$ in thickness. Mixed layer depth varied with weather conditions, reaching a maximum recorded thickness of Ca $100 \mathrm{~m}$ following a northeast gale April 11, 1988.

Benthic process rates. During 1990, a benthic-landing free vehicle (Smith et al. 1976, Smith \& Baldwin 1983) was deployed from the 'Baffin' at several locations in Conception Bay. The benthic lander places 2 incubation chambers over the sediment-water inter-

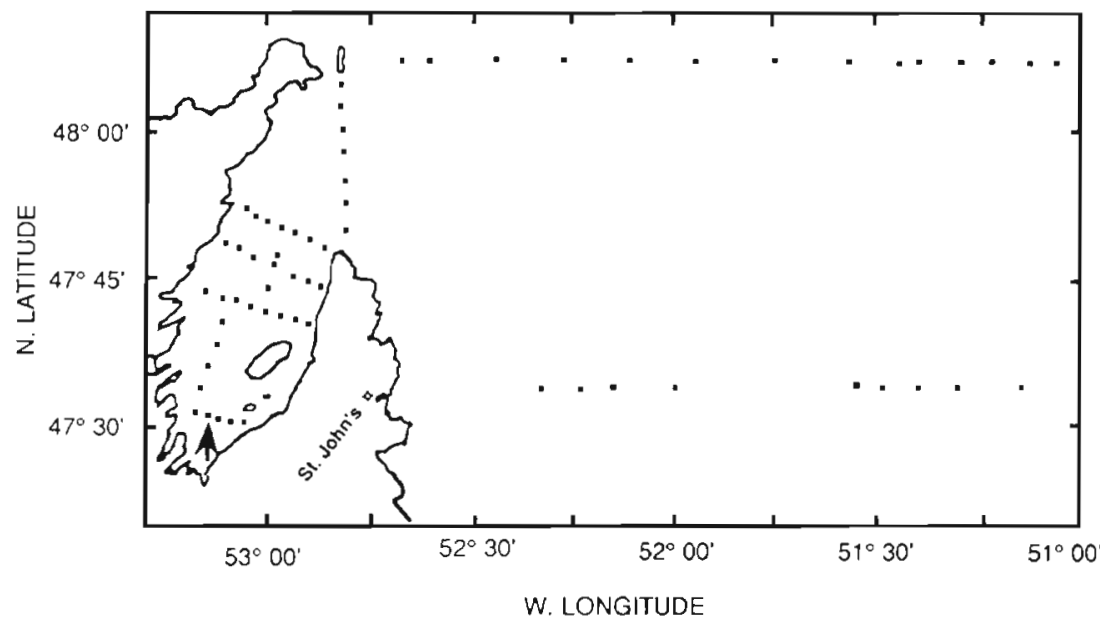

Fig. 1 Conception Bay and Avalon Channel between Newfoundland and Grand Bank, showing the distribution stations occupied on the 'Baffin' cruises. Arrow at head of bay designates sediment trap station. Precise station locations are listed in Table 4 
face. Increases and decreases of oxygen and metabolites within the chambers are used to infer fluxes into or out of the sediments. Oxygen concentration is monitored continuously using polarographic electrodes, and the dissolved nutrients ammonium, nitrate, nitrite, urea, phosphate, and silicate are sampled over time using $60 \mathrm{~cm}^{3}$ hypodermic syringes. A command system, including a Benthos Model 210 acoustic commandable transponder and a modified Williams Timed Release, is used for initiating multiple burn-wire release latches to lower the chambers after the lander reaches bottom, to take a sequence of syringe samples, and finally to drop anchor weights. The 2 benthic chambers each include an oxygen sensor with internal thermistor, a submersible pump, an additional stirring motor, and three $60 \mathrm{~cm}^{3}$ syringes. The syringe samples are pre-filtered with $0.2 \mu \mathrm{m}$ filters. Each chamber encloses an area of $905 \mathrm{~cm}^{2}$, but volumes can be varied from 5 to $9 \mathrm{l}$ by an adjustable collar which stops penetration at a predetermined depth of 2 to $5 \mathrm{~cm}$. Each chamber contains a stirring bar powered by an oil-filled electric motor that rotates a small magnet outside the chamber. A Sea Bird Sealogger SBE 20 is used to power 2 external polarographic oxygen sensors and 2 submersible pumps. The submersible pumps draw water from inside the chambers and direct the flow onto the sensor membranes. The return flow from the oxygen sensor manifolds is directed back into the chamber through a baffle to prevent resuspension of bottom sediments. One-way valves on the tops of each chamber allow water to escape as they sink into the bottom. The open lip of each chamber is sharpened to allow it to penetrate the sediments. An open syringe needle which penetrates each chamber allows outside water to replace that drawn from the chambers without pulling pore water out of the sediments when syringe samples are taken. Data are recorded on the data logger which stores the voltage outputs from the temperature and oxygen sensors in the chambers. Final computation of dissolved oxygen is made using calibration values obtained in the laboratory and conversion formulas which are part of the software of the Sea Bird data logger.

After the lander has reached bottom, a period of 15 to $30 \mathrm{~min}$ is allowed for settling of any disturbed sediments before the flux chambers are lowered to the bottom by acoustic command from the surface. Video records show that bottom disturbance does occur when the lander framework hits bottom, but hydraulic dampers attached to both ends of the chamber assembly slow chamber descent onto the substrate. The chambers remain on the bottom over periods of several hours to several days, depending on the expected rate of oxygen flux and the resulting time required to obtain a reliable time-series measurement. Three water sam- ples are taken from each chamber by acoustic command, or at timed intervals controlled by the timed release, for later analysis of dissolved nutrient concentration.

Video camera recordings are coordinated with timed or acoustic manipulations in order to monitor critical experimental parameters, including possible sediment disturbance during chamber lowering, depth and/or success of chamber penetration, function of syringe withdrawals, or disturbances by large animals. A sensitive hydrophone picks up critical sounds, such as acoustic signals, motor drive, and weight drops. On recovery aboard ship, the videotapes are viewed to assess the relative success of the sequence on the bottom. Syringe samples were analyzed for dissolved inorganic nutrients and the oxygen data were reduced into graphical output for interpretation. The syringes were not poisoned, but the water was pre-filtered through $0.2 \mu \mathrm{m}$ filters to prevent entrance of all but the smallest bacteria.

Sediment traps and flocculent layer collection. During 1988 and 1990, sediment traps (polyvinyl chloride cylinders $10 \mathrm{~cm}$ in diameter, aspect ratio 6, no baffle, no poison) were deployed at several depths on a tautbuoyed mooring located at $47^{\circ} 32.2^{\prime} \mathrm{N}, 53^{\circ} 07.9^{\prime} \mathrm{W}$, off Brigus lighthouse (Fig. 1). Traps were changed at weekly intervals and occasionally more often, weather permitting. Sediment trap contents were returned to the laboratory packed in ice and were used experimentally the same day. In 1988, a flocculent layer was collected by gently lowering core tubes $(7.5 \mathrm{~cm}$ diameter) into the bottom and recovering both the core material and the undisturbed overlying water. The coring device was attached to a modified Petersen grab (sampling area $0.5 \mathrm{~m}^{2}$ ) with parabolic jaws (D. Peer, Bedford Institute of Oceanography, Dartmouth, N. S., Canada; pers. comm.). Samples of the distinct flocculent layer and the overlying water were collected with a pipette, after which the samples were packed in ice and returned to the laboratory for use the same day. Attempts to collect samples of flocculent layers in 1990 were unsuccessful in that there was no evidence of a concentrated flocculent layer from core samples in Conception Bay. Video records from the benthic lander showed a visually detectable but not intense nepheloid layer.

Photosynthesis. To measure photosynthesis, water samples were collected in the chlorophyll-maximum layer using Niskin samplers with silicone elastic closures. Acid-cleaned, $50 \mathrm{ml}$, polystyrene tissue culture flasks were filled with water, ${ }^{14} \mathrm{C}$-bicarbonate (DuPont NEN) was added, and the bottles were exposed to sunlight in chilled seawater or ice, as needed, in a deck incubator. Measurements were made between 09:00 h and 16:00 h. Temperature in the 
incubator was monitored, and only observations during which we maintained temperature within $2 \mathrm{C}^{\circ}$ of the insitu temperature are reported here. Photosynthetically active light reaching the flasks was controlled from 1 to $100 \%$ by placing a varying thickness of Rohm \& Haas 2424 blue acrylic on the top of the incubator. After a $4 \mathrm{~h}$ exposure, the water was filtered, at $<10 \mathrm{~cm} \mathrm{Hg}$ vacuum, through $0.2 \mu \mathrm{m}$ membrane filters and the radioactivity of the residue was counted. Aliquots of the filtrate were acidified to remove bicarbonate and $\mathrm{CO}_{2}$, and the radioactivity of the residual dissolved organic carbon (DOC) was counted. At the time of sample collection, a light attenuation profile of the water column was recorded, using a Li-Cor quanta meter with a spherical underwater sensor and a cosine-corrected, flat above-water sensor. Photosynthesis was estimated by relating the rates obtained in the incubator to the irradiance/depth profile and interpolating between points. The $1 \%$ light intensity occurred at 30 to $50 \mathrm{~m}$, and while chlorophyll concentrations usually were high throughout the mixed layer, there was frequently a pronounced chlorophyll maximum (Fig. 2). Since error might result from the use of a water sample from only one depth, we also calculated photosynthesis from the photosynthesis/irradiance relationship using the equation of Jassby \& Platt (1976). While some vertical variation in the value of $\alpha$ is known to occur (Platt \& Jassby 1976), this approach is relatively independent of the effects of phytoplankton population density. Phytosynthesis calculated by the Jassby-Platt equation was similar to, but usually slightly higher than, our empirical interpolation.

Production of heterotrophic bacteria. Thymidine uptake was measured by the method of Wicks \& Robarts (1987), using [methyl ${ }^{3} \mathrm{H}$ ]-thymidine, $84 \mathrm{Ci}$ $\mathrm{mmol}^{-1}$ (DuPont-NEN). The final concentration of thymidine was $5 \mathrm{nM}$. Seawater was collected immediately from Niskin bottles and kept packed in ice. Samples collected aboard C.S.S. 'Baffin' were processed within $30 \mathrm{~min}$. Samples collected aboard 'Shamook' or 'Karl and Jackie II' were returned to the laboratory and processed the same day. Sterile Whirl-Pak ${ }^{\circledR}$ bags in a refrigerated water bath at simulated in-situ temperature were loaded with $10 \mathrm{ml}$ of sample water. Label was added to the bags at zero time. Because previous experience led us to expect very low rates of thymidine incorporation, all uptake rates were measured as timecourse experiments over 4 to $12 \mathrm{~h}$. Uptake was always linear for at least $12 \mathrm{~h}$. Our limit of detection was 0.005 pmol $1^{-1} h^{-1}$. Both zero time and killed controls were prepared by adding $\mathrm{NaOH}$. There was no significant difference between zero-time samples and killed controls that were filtered at the time of filtration of the final sample. The Wicks and Robarts extraction yielded estimates of thymidine uptake about half of those with the cold trichloracetic acid (TCA) method of Fuhrman \& Azam (1980).

Bacterial production was also estimated from incorporation of $\mathrm{L}-\left[3,4,5-{ }^{3} \mathrm{H}-(\mathrm{N})\right]$-leucine, $150 \mathrm{Ci} \mathrm{mmol}{ }^{-1}$ (DuPont-NEN), following the methods of Kirchman et al. (1985), Chin-Leo \& Kirchman (1988), and Kirchman \& Hoch (1988). Ten-ml aliquots of sea water, made 10 $n M$ with leucine, were placed in sterile Whirl-Pak ${ }^{\circledR}$ bags and $1 \mu \mathrm{Ci}$ of ${ }^{3} \mathrm{H}$-leucine added. After incubation at in-situ temperature for 4 to $8 \mathrm{~h}$, triplicate samples were killed by adding $1 \mathrm{ml}$ of $50 \%$ TCA. The samples were then heated at $95^{\circ} \mathrm{C}$ for $30 \mathrm{~min}$, rinsed twice with $5 \%$ TCA and once with distilled water, and the residues collected on $0.2 \mu \mathrm{m}$ Sartorius cellulose nitrate membrane filters. Killed controls processed with the last set of samples were in agreement with the zero time samples. Periodically during the research, time course experiments were conducted for up to $12 \mathrm{~h}$ duration. Uptake was always linear for at least $10 \mathrm{~h}$. Incubations of less than $4 \mathrm{~h}$ duration were likely to show little assimilation, and almost all deep-water samples did not show significant leucine incorporation after $8 \mathrm{~h}$. Bacterial protein and organic carbon production were estimated following the calculation procedure of Simon \& Azam (1989), assuming a 2-fold isotope dilution.

Results with the thymidine and leucine methods may be quite different, because they measure processes that change differently through the cycle of cell division or may respond differently to unbalanced growth. Simon \& Azam (1989) provide instances of differential results. Chin-Leo \& Kirchman (1988) discuss the possible reasons for observed disparities, but they point out that both methods are within the range of precision that can be expected.

Leucine concentration in Conception Bay water was estimated by the isotope-dilution method of Wright \& Hobbie (1966). Water samples were delivered from Niskin or Go-Flo bottles into chilled polystyrene bottles and held in ice water during preparation. Leucine was added to triplicate $10 \mathrm{ml}$ aliquots to make them $0,1,5,10$, 20 , and $50 \mathrm{nM}$. One $\mu \mathrm{Ci}$ of ${ }^{3} \mathrm{H}$-leucine, $\mathrm{L}-\left[3,4,5-{ }^{3} \mathrm{H}(\mathrm{N})\right]$ (Du-Pont NEN, $150 \mathrm{Ci} \mathrm{mmol}{ }^{-1}$ ) was added to each, increasing the added carrier $0.65 \mathrm{nM}$. Triplicate zero time aliquots were prepared as well as killed controls which were carried through with the samples. After $8 \mathrm{~h}$ the series was killed by the addition of $1 \mathrm{ml}$ of $50 \%$ TCA. The aliquots were heated at 90 to $99^{\circ} \mathrm{C}$ for $30 \mathrm{~min}$, cooled, and the protein precipitate collected on Sartorius cellulose nitrate filters of $0.2 \mu \mathrm{m}$ porosity. The filters were washed twice with 5\% TCA and twice with distilled water, dried, and counted in a Packard Tri-Carb 4000 scintillation counter, using both internal and external standards. Linear kinetics, as described by Wright \& Hobbie (1966), were observed in all cases. Fuhrman \& Ferguson (1986) found that estimates of amino acid 
concentration by the isotope-dilution technique compare favorably with HPLC analyses, but since we do not have independent analytical measures of DFAA's, our measurements of $\mathrm{k}+\mathrm{s}$ are overestimates, depending on the magnitude of $\mathrm{k}$ (Wright \& Hobbie 1965).

Bacterial numbers. Water samples for bacterial counts were preserved in acid Lugol's and refrigerated (Pomroy 1984, Nishino 1986). Bacteria were counted by the acridine orange direct-count method (Hobbie et al. 1977) as modified by Douglas et al. (1987) to produce strong, long-lasting fluorescence.

Enrichment experiments. Seawater held in ice was amended with pre-chilled glucose and peptone solutions to simulate concentrations of labile substrates ranging from those present in the spring phytoplankton bloom $\left(0.15 \mathrm{mg} \mathrm{l}^{-1}\right)$ to those approaching typical laboratory cultures ( $1500 \mathrm{mg} \mathrm{l}^{-1}$ ). Blooms typically contain amino acids in the micromolar range (Andrews \& Williarns 1971, Morita et al. 1977, Burney et al. 1982, Haberstroh et al. 1987), while cultures contain millimolar concentrations. In the absence of blooms, seawater contains nanomolar quantities of free amino acids (Bohling 1970, Schell 1974, Billen et al. 1980, Macko \& Green 1982, Mopper \& Lindroth 1982). The amended water was dispended into pre-chilled $20 \mathrm{ml}$ vials in an ice bath, capped without an air bubble, and placed in incubators in the dark at $-2,+2$, and $+6^{\circ} \mathrm{C}$ in 1986 , and $-1,+3.5$, and $+15^{\circ} \mathrm{C}$ in 1990 . In 1986 , sets of 3 vials were removed at intervals, brought to $0^{\circ} \mathrm{C}$, and dissolved oxygen was measured with a Radiometer E5046 electrode and PHM71 Mark 2 analyzer. Readings were corrected for salinity and barometric pressure. In 1990 , oxygen was measured in triplicate samples with a semimicro Winkler titration. Since growth of bacteria on the walls of the vial could potentially bias results, wall growth was monitored throughout the experiments by the addition of cover glasses to the vials. As vials were opened for sampling, the cover glasses were removed, stained with acridine orange, and the attached bacteria were counted. Little wall growth was observed, never enough in terms of bacterial numbers to bias results.

Separate analyses of variance were performed on each of the enrichment experiments. In the data from the 1986 experiment, 15 of 49 respiration values were negative. These observations were removed prior to analysis. If these observations were included as zeroes, the conclusions of the analysis would be substantially altered. All observations were $\log _{10}$ transformed to stabilize the heterogeneity of variance. Prior to transformation, the constant, 0.001 , was added to all observations in order to accomodate the observed values of zero. In the 1990 experiments, analyses were performed using means of log-transformed values from each set of replicate vials sampled at each time for each treatment combination. In all analyses, residual plots were used to verify the assumptions of independence, normality, and constant variance.

\section{RESULTS}

\section{Spring bloom development}

The years 1986,1988 , and 1990 provided a contrast in spring bloom development. The spring of 1986 was unusually warm, calm, and sunny, with no pack ice. Onset of phytoplankton bloom in late March was sudden, intense, and short, ending in mid-April. The upper mixed layer, which was $-1{ }^{\circ} \mathrm{C}$ at the onset of the bloom, warmed to 1 to $2{ }^{\circ} \mathrm{C}$ during late phases in early May. Water below the pycnocline remained below $0{ }^{\circ} \mathrm{C}$ at all times. March 1988 was comparatively mild, and the spring bloom was beginning by mid-March, with an isothermal water column stratified by a brackish surface layer, rather than the classical warm surface layer (Fig. 2). April and May 1988 were cold and stormy, with a moderate influx of sea ice and bergs during April. Because of frequent upward mixing of nutrients by gales, the spring bloom continued throughout April and May, terminating in early June. March 1990 was cold and stormy, with extensive sea ice in Conception Bay. April was relatively warm and calm, permitting development of a thermocline (Fig. 3). May was cool and cloudy, with frequent gales. The spring bloom in 1990 terminated in mid-May, but some of the diatoms remained suspended in deep water late in the month (Fig. 4). The 3 yr thus present a broad range of possible spring events: a short-lived, intense bloom in 1986, a bloom lasting nearly 3 mo in 1988, and a bloom of intermediate duration in 1990.

Development of the spring bloom in 1988 and 1990 was monitored by CTD-fluorometer casts (Table 1). On 24 March 1988, chlorophyll was $<1 \mathrm{mg} \mathrm{m}^{-3}$ at all depths, but by 7 April a chlorophyll maximum layer had developed in the upper $15 \mathrm{~m}$. The chlorophyll concentration at the depth of the maximum increased in early April, decreased for $2 \mathrm{wk}$ in mid-April, and then increased in late April to early May to near the concentrations of early April. The depth of the $>1 \mathrm{mg}$ $\mathrm{m}^{-3}$ isopleth increased continuously, however, until April 29, remaining nearly constant until May 9, suggesting that the highest phytoplankton concentrations per $\mathrm{m}^{2}$ occurred near the end of the bloom. Thereafter the bloom diminished, and after 1 June chlorophyll was again $<1 \mathrm{mg} \mathrm{m}^{-3}$ at all depths (data not shown).

\section{Photosynthesis}

High rates of photosynthesis were found in early April 1988, decreasing after 13 April (Table 1). Photo- 

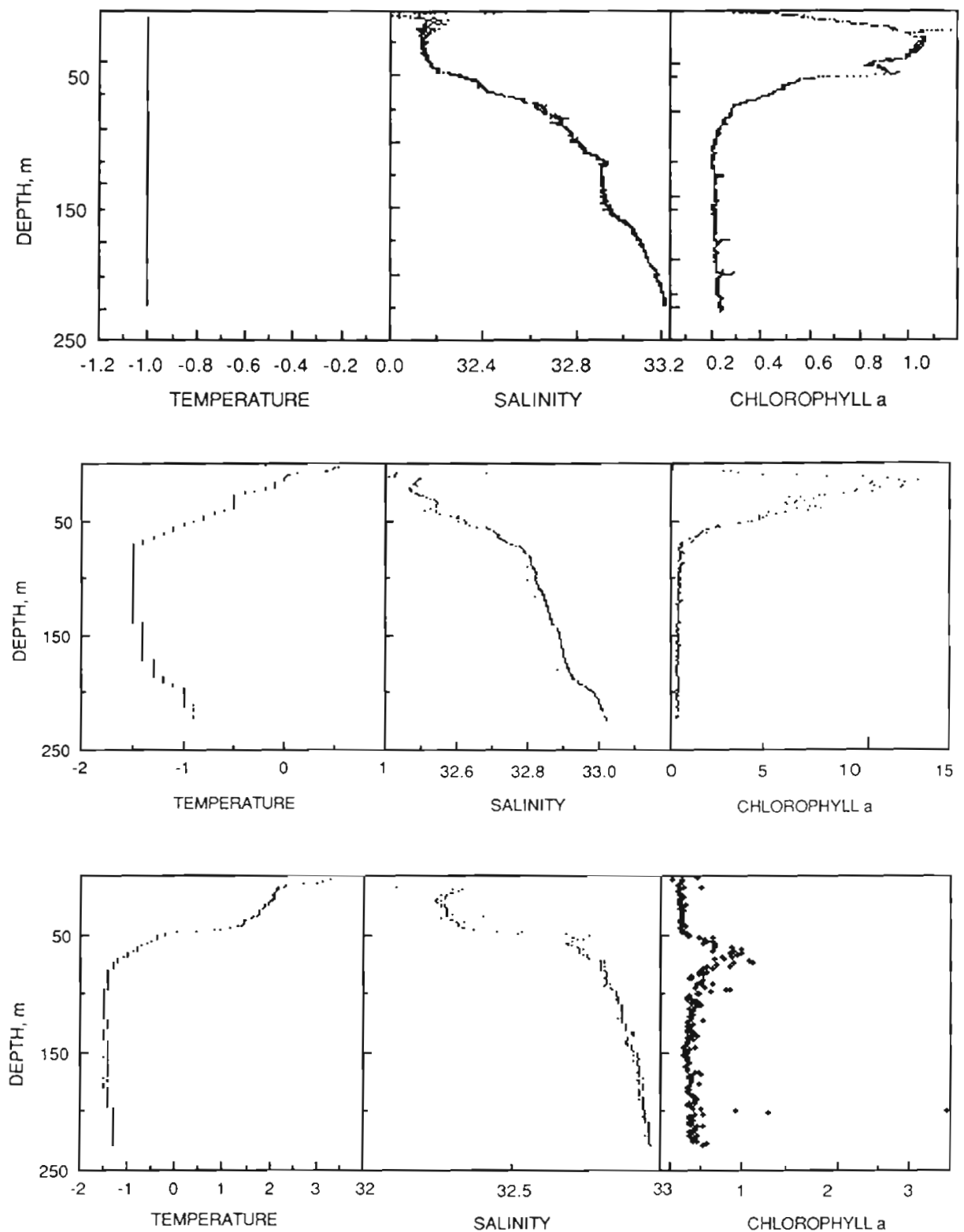

Fig. 2. Temperature $\left({ }^{\circ} \mathrm{C}\right)$ salinity (psu) and chlorophyll a fluores cence $\left(\mathrm{mg} \mathrm{m}^{-3}\right)$, plotted directly from the downcast record of a Seabird CTD at the sediment trap station off Brigus in Conception Bay, Newfoundland, 19 March 1988, 15:15 h, very early in the development of the spring bloom. Water stability was controlled entirely by salinity on this occasion

Fig. 3. Temperature $\left({ }^{\circ} \mathrm{C}\right)$ salinity (psu) and chlorophyll a fluorescence $\left(\mathrm{mg} \mathrm{m}^{-3}\right)$, plotted directly from the downcast of a Seabird CTD at the sediment trap sation off Brigus in Conception Bay, Newfoundland, 18 April 1990, at the peak of the spring bloom. Data are bin averaged at $1 \mathrm{~m}$ intervals. Chlorophyll calibrated by HPLC of water samples

Fig. 4. Temperature $\left({ }^{\circ} \mathrm{C}\right)$ salinity (psu), and chlorophyll a fluorescence $\left(\mathrm{mg} \mathrm{m}^{-3}\right)$, plotted directly from the downcast of a Seabird CTD at the sediment trap station off Brigus in Conception Bay, Newfoundland, 29 May 1990, after the collapse of the spring bloom. Note the thin layer of high fluorescence remaining in the water at $200 \mathrm{~m}$. Data are bin averaged at $1 \mathrm{~m}$ intervals. Chlorophyll calibrated by HPLC of water samples synthetic rates can be divided into 2 sets; early bloom from 9 to 13 April (mean $\pm 1 \mathrm{SE}=5.2 \pm 2.76 \mathrm{~g} \mathrm{C} \mathrm{m}^{-2}$ $\left.\mathrm{d}^{-1}\right)$ and late bloom from 16 April to 5 May $(0.51$ $\left.\pm 0.17 \mathrm{~g} \mathrm{C} \mathrm{m}^{-2} \mathrm{~d}^{-1}\right)$. However, the chlorophyll concentration in the euphotic zone remained high and actually increased, with increased water stability, in early May Thus, chlorophyll concentration was not a good predictor of primary production. Since our photosynthesis measurements were largely limited to a single station near the head of Conception Bay, they only indicate the magnitude of primary production in the Bay or the region. These observations do verify that the spring bloom in 1988 was continuous from late March to May, as shown by the CTD-fluorometer records which were taken on nearly all occasions of water sampling $(>100$ CTD stations in each spring season). Because we mea- sured both carbon fixed in phytoplankton cells and carbon fixed in released dissolved organic compounds, we can calculate the net per cent of photosynthate released in $4 \mathrm{~h}$ incubations. Our tracer experiments with amino acids indicate that the rate of bacterial utilization of DOC was low. In 7 out of 8 cases, $<20 \%$ of photosynthate was found as DOC; release of $>50 \%$ was observed in one instance. The largest releases of dissolved photosynthate occurred either at $100 \%$ or $>10 \%$ of incident irradiance (data not shown).

\section{Bacterial numbers and production}

Acridine orange counts of bacteria in the water showed little response to the spring bloom (Table 2). 
Table 1. Chlorophyll a concentration at the chlorophyll maximum, chlorophyll a from CTD-fluorometer data integrated to 40 and $100 \mathrm{~m}$, and total carbon fixed in the water column. All data are from the sediment-trap mooring station in Conception Bay $\left(47^{\circ}\right.$ $\left.32.2^{\prime} \mathrm{N}, 53^{\circ}, 07.9^{\prime} \mathrm{W}\right)$, except 9 April, which is from the Avalon Channel $\left(48^{\circ}, 07.4^{\prime} \mathrm{N}, 51^{\circ} 44.2^{\prime} \mathrm{W}\right)$, between the Grand Banks and Newfoundland. Water for photosynthesis measurement was taken from the depth of the chlorophyll maximum

\begin{tabular}{|c|c|c|c|c|c|c|c|c|c|}
\hline \multirow[t]{2}{*}{$\begin{array}{l}\text { Date } \\
(1988)\end{array}$} & \multirow[t]{2}{*}{$\begin{array}{l}\text { Chl max. } \\
\text { depth }(m)\end{array}$} & \multirow{2}{*}{$\begin{array}{c}1 \mathrm{mg} \mathrm{m}^{3} \\
\text { isopleth } \\
\text { depth }(\mathrm{m})\end{array}$} & \multirow{2}{*}{$\begin{array}{l}\left(\mathrm{mg} \mathrm{m}^{-3}\right) \\
\text { Maximum }\end{array}$} & \multirow{2}{*}{$\begin{array}{c}\text { Chlorophyll a } \\
\left(\mathrm{mg} \mathrm{m}^{-2}\right) \\
0-40 \mathrm{~m}\end{array}$} & \multirow{2}{*}{$\underset{0-100 \mathrm{~m}}{\left(\mathrm{mg} \mathrm{m}^{-2}\right)}$} & \multicolumn{4}{|c|}{$\begin{array}{l}\text { Carbon fixed } \\
\left(\mathrm{g} \mathrm{C} \mathrm{m}^{-2} \mathrm{~d}^{-1}\right)\end{array}$} \\
\hline & & & & & & Particulate & Dissolved & Total & $\%$ DOC \\
\hline $24 \mathrm{Mar}$ & na & na & 0.6 & 22 & 28 & 0.05 & 0.02 & 0.07 & 29 \\
\hline $9 \mathrm{Apr}$ & 15 & 25 & 4.5 & 100 & 110 & 1.01 & 2.22 & 3.23 & 69 \\
\hline $11 \mathrm{Apr}$ & 20 & 45 & 3.0 & 128 & 195 & 9.17 & 0.31 & 9.47 & 3 \\
\hline $13 \mathrm{Apr}$ & 25 & 80 & 1.4 & 98 & 249 & 2.26 & 0.32 & 2.58 & 9 \\
\hline $16 \mathrm{Apr}$ & 28 & 85 & 1.8 & 99 & 205 & 0.59 & 0.04 & 0.63 & 6 \\
\hline $25 \mathrm{Apr}$ & 45 & 88 & 1.8 & 64 & 125 & 0.41 & 0.10 & 0.51 & 20 \\
\hline $29 \mathrm{Apr}$ & 46 & 92 & 3.5 & 58 & 184 & 0.36 & 0.08 & 0.44 & 18 \\
\hline 7 May & 20 & 93 & 3.2 & 134 & 239 & 0.54 & - & - & - \\
\hline 9 May & 40 & 92 & 2.1 & 145 & 272 & 0.73 & 0.11 & 0.84 & 13 \\
\hline
\end{tabular}

Table 2. Acridine orange direct counts of bacteria at the sediment trap mooring site in conception Bay, Newfoundland, $47^{\circ} 41.1^{\prime} \mathrm{N}$ $53^{\circ} 07.9^{\prime} \mathrm{W}$, during and after spring blooms of 1986 and 1990

\begin{tabular}{|rrrrrr|}
\hline Year & Depth range $(\mathrm{m})$ & $10^{5}$ cells $\mathrm{ml}^{-1}$ & $\pm 1 \mathrm{SE}$ & $\%$ Dividing & $\pm 1 \mathrm{SE}$ \\
\hline 1986 & $0-100$ & 4.12 & 0.47 & 3.19 & 0.42 \\
1986 & $101-250$ & 1.91 & 0.17 & 2.22 & 0.44 \\
1990 & $0-100$ & 3.29 & 0.72 & & 13 \\
1990 & $101-257$ & 1.52 & 0.21 & & 14 \\
\hline
\end{tabular}

Numbers were seldom much more than $10^{5} \mathrm{ml}^{-1}$, and rarely reached $10^{6} \mathrm{ml}^{-1}$. The unusually low frequency of dividing cells during the 1986 bloom (Table 2) suggests very long doubling times. Large numbers of bacteria were found in our core-tube sample of the flocculent layer in 1988 . They were predominantly 1 to $2 \mu \mathrm{m}$ rods rather than the smaller-sized, mixed community of cocci, crescents, and small rods found throughout the water column. Considerable diversity in bacterial morphology was observed in the water column. Some unusual aspects of this are considered further in the discussion section.

In 1988, of 25 measurements of thymidine uptake by bacterioplankton in the water column, excepting the near-bottom flocculent layer, only 13 showed thymidine incorporation significantly greater than zero over time courses of 5 to $12 \mathrm{~h}$ (Table 3). All but two of the metabolically active samples were taken at depths of 15 to $25 \mathrm{~m}$, in the chlorophyll maximum. In both of these cases (135 m on 15 April and $70 \mathrm{~m}$ on 29 April) the diatom bloom in the upper mixed layer was at its peak, and fallout of phytoplankton to depth was beginning, as shown by in situ fluorescence data from the CTD (data not shown). Twelve samples taken from 55 to $200 \mathrm{~m}$ revealed no significant incorporation of thymidine. Four values were $>2 \mathrm{pmol} \mathrm{l}^{-1} \mathrm{~h}^{-1}$, and these were exclusively from the upper euphotic zone. All others with significance above zero were in the range 0.5 to 2 .

Samples taken in the flocculent layer in 1988 showed thymidine uptake comparable to the highest rates in the chlorophyll maximum layer (Table 3). Very high thymidine uptake rates were found in undiluted samples taken from sediment traps at $100 \mathrm{~m}$ at $-1{ }^{\circ} \mathrm{C}$. The sediment trap material collected on May 13 was a maximum of $3 \mathrm{~d}$ old, with a seston concentration of 0.56 $\mathrm{mg} \mathrm{Cl} \mathrm{C}^{-1}$, that collected on April 19 was a maximum of $13 \mathrm{~d}$ old, with a seston concentration of $5.7 \mathrm{mgC}^{-1}$; both samples having been at a temperature of $-1{ }^{\circ} \mathrm{C}$ during the collection period and not above $0^{\circ} \mathrm{C}$ during transportation and handling of the samples.

Leucine incorporation rates during the 1990 bloom, shown in Table 4, like those of thymidine in 1988, were sometimes substantial in the chlorophyll maximum, which was usually between 10 and $30 \mathrm{~m}$, while uptake in the deep water was low to undetectable. There was only one exception, on 30 April at $90 \mathrm{~m}$, which on the basis of in situ fluoremetry could be attributed to accumulation of the sinking phytoplankton bloom on a deep pycnocline. With one exception, upper water column bacterial production values $(<30 \mathrm{~m})$ were always much greater than those found in deep water. The one exception, the only post-bloom sample taken, is perhaps instructive, since both surface and deep values 
were low. Further, one can see in the data for the sediment trap station off Brigus $\left(47^{\circ} 32.2^{\prime} \mathrm{N}\right.$, $\left.53^{\circ} 0.79^{\prime} \mathrm{W}\right)$ a steady decline in bacterial production from 18 April through 2 May, coinciding with the decline of the bloom as decumented by CTD fluorometry (data not shown).

Concentration of dissolved free leucine in the water during the 1990 bloom, estimated as $\mathrm{k}+\mathrm{s}$ by isotope dilution, ranged from undetectable to a maximum of 25 $n M$. All concentrations $>10 \mathrm{nM}$ occurred either in the chlorophyll maximum in the upper mixed layer or within $10 \mathrm{~m}$ of the bottom. However, at least 2 samples in the chlorophyll maximum contained barely detectable leucine concentrations. The mean leucine concentration in the upper mixed layer was $7.4 \mathrm{nM} \pm 3.5$ (mean \pm 1 $\mathrm{SE}_{;} \mathrm{n}=5$ ). The mean leucine concentration in the core of the Labrador Current water, below $100 \mathrm{~m}$, was $2.1 \pm$ $1.57 \mathrm{nM}(\mathrm{n}=5)$. Three samples taken 2 to $10 \mathrm{~m}$ above the bottom were $15 \pm 6.0 \mathrm{nM}$. Mean turnover time of leucine, based on 14 isotope dilution experiments in 1990 , was $7.7 \pm 3.6 \mathrm{~h}$ with a range of $<1$ to $50 \mathrm{~h}$. Turnover time of leucine, estimated from the intercepts of the Wright-Hobbie plots, varied from $<1$ to $50 \mathrm{~h}$, with a mean of $7.7 \pm 3.6\left(\right.$ mean $\left.\pm 1 \mathrm{SE}_{i} \mathrm{n}=14\right)$.

Table 3. Uptake of tritiated thymidine by natural populations of bacteria at the sediment trap station in Conception Bay, Newfoundland, and in the Avalon Channel (A) on the inner edge of Grand Bank. Bacterial production is calculated based on the assumption of $10^{9}$ cells nmol ${ }^{-1}$ (Bell 1990). Flocculent layer is first $10 \mathrm{~cm}$ of water above bottom, sampled from core tubes; 'Over floc.' is next $10 \mathrm{~cm}$ of water in core tubes. Limit of resolution $=<0.005 \mathrm{pmol} \mathrm{l}^{-1} \mathrm{~h}^{-1}$

\begin{tabular}{|c|c|c|c|c|c|c|}
\hline $\begin{array}{l}\text { Date } \\
(1988)\end{array}$ & $\begin{array}{l}\text { Depth } \\
\text { (Im) }\end{array}$ & $\begin{array}{l}\text { Temp. } \\
\left({ }^{\circ} \mathrm{C}\right)\end{array}$ & $\begin{array}{c}\text { Assimilation } \\
\left(\mathrm{pmol}^{-1} \mathrm{~h}^{-1}\right)( \pm \mathrm{SE})\end{array}$ & $\begin{array}{r}\text { Bacteria } \\
\left(\mathrm{mgC} \mathrm{m}^{-3} \mathrm{~d}^{-1}\right)\end{array}$ & $\begin{array}{l}\text { oduction } \\
\qquad\left(\mathrm{mgC} \mathrm{m}^{-2} \mathrm{~d}^{-1}\right)\end{array}$ & $\begin{array}{l}\text { Turnover } \\
\text { (d) }\end{array}$ \\
\hline \multicolumn{7}{|l|}{ Water } \\
\hline $9 \operatorname{Apr}(\mathrm{A})$ & $\begin{array}{l}10 \\
55 \\
95\end{array}$ & $\begin{array}{l}-1.8 \\
-1.8 \\
-1.8\end{array}$ & $\begin{array}{l}0.38(0.007) \\
0.47^{\cdot}(0.26) \\
0.009^{\bullet}(0.021)\end{array}$ & $\begin{array}{l}0.18 \\
0.23 \\
0.004\end{array}$ & 11.67 & $\begin{array}{r}2.74 \\
2.20 \\
116.0\end{array}$ \\
\hline $11 \mathrm{Apr}$ & $\begin{array}{r}15 \\
200\end{array}$ & $\begin{array}{l}+0.6 \\
-1\end{array}$ & $\begin{array}{l}1.03(0.03) \\
0.05(0.03)\end{array}$ & $\begin{array}{l}0.49 \\
0.02\end{array}$ & 11.66 & $\begin{array}{r}1.0 \\
43.5\end{array}$ \\
\hline $13 \mathrm{Apr}$ & $\begin{array}{r}15 \\
125\end{array}$ & $\begin{array}{l}-0.5 \\
-1.2\end{array}$ & $\begin{array}{l}3.962(1.0) \\
0^{\circ}\end{array}$ & $\begin{array}{l}1.90 \\
0\end{array}$ & 27.24 & $\begin{array}{l}0.27 \\
\mp\end{array}$ \\
\hline $14 \mathrm{Apr}$ & $\begin{array}{r}15 \\
110\end{array}$ & $\begin{array}{l}-0.5 \\
-1.0\end{array}$ & $\begin{array}{l}1.985(0.52) \\
0^{*}\end{array}$ & $\begin{array}{l}0.95 \\
0\end{array}$ & 13.67 & $\begin{array}{l}0.52 \\
+\end{array}$ \\
\hline $15 \mathrm{Apr}$ & $\begin{array}{r}25 \\
135 \\
150 \\
200\end{array}$ & $\begin{array}{l}-0.5 \\
-1.2 \\
-1.2 \\
-1.0\end{array}$ & $\begin{array}{l}1.69(0.29) \\
0.287(0.04) \\
0 \cdot \\
0.005 \cdot(0.008)\end{array}$ & $\begin{array}{l}0.81 \\
0.14 \\
0 \\
0\end{array}$ & 33.79 & $\begin{array}{l}0.62 \\
43 \\
+ \\
+\end{array}$ \\
\hline 16 Apr & 25 & -0.4 & $0.953(0.33)$ & 0.46 & 10.85 & 1.09 \\
\hline $17 \operatorname{Apr}(\mathrm{A})$ & $\begin{array}{l}20 \\
95\end{array}$ & $\begin{array}{l}-0.7 \\
-1.1\end{array}$ & $\begin{array}{l}2.44(0.15) \\
0^{\circ}\end{array}$ & $\begin{array}{l}1.17 \\
0\end{array}$ & & $\begin{array}{l}0.43 \\
t\end{array}$ \\
\hline $25 \mathrm{Apr}$ & $\begin{array}{r}7 \\
70\end{array}$ & $\begin{array}{l}+0.37 \\
-1.3\end{array}$ & $\begin{array}{l}2.288(0.06) \\
0.038(0.04)\end{array}$ & $\begin{array}{l}1.10 \\
0.02\end{array}$ & 8.51 & $\begin{array}{l}0.46 \\
27.8\end{array}$ \\
\hline 29 Apr & $\begin{array}{l}10 \\
70\end{array}$ & $\begin{array}{l}+1 \\
-1\end{array}$ & $\begin{array}{l}0.92(0.10) \\
0.28 \cdot(0.23)\end{array}$ & $\begin{array}{l}0.44 \\
0.14\end{array}$ & 12.03 & $\begin{array}{l}13.6 \\
45.5\end{array}$ \\
\hline 11 May & $\begin{array}{r}25 \\
110\end{array}$ & $\begin{array}{l}-1 \\
-1\end{array}$ & $\begin{array}{l}0.060(0.020) \\
0.020^{\circ}(0.008)\end{array}$ & $\begin{array}{l}0.03 \\
0.01\end{array}$ & 1.05 & $\begin{array}{l}17.2 \\
52.6\end{array}$ \\
\hline 16 May & $\begin{array}{r}40 \\
150 \\
175\end{array}$ & $\begin{array}{r}0 \\
-1 \\
-1\end{array}$ & $\begin{array}{l}0.143(0.006) \\
0.060 \cdot(0.008) \\
0.005 \cdot(0.003)\end{array}$ & $\begin{array}{l}0.07 \\
0.03 \\
0\end{array}$ & 5.5 & $\begin{array}{r}90.9 \\
17.2 \\
208.3\end{array}$ \\
\hline \multicolumn{7}{|c|}{ Sediment trap material } \\
\hline $\begin{array}{l}19 \text { Apr } \\
4 \text { May } \\
13 \text { May }\end{array}$ & $\begin{array}{l}100 \\
100 \\
100\end{array}$ & $\begin{array}{l}-1 \\
-1 \\
-1\end{array}$ & $\begin{array}{r}0.91(0.09) \\
8.41(1.82) \\
15.23(0.62)\end{array}$ & $\begin{array}{l}0.44 \\
4.04 \\
7.31\end{array}$ & & $\begin{array}{l}1.14 \\
0.12 \\
0.07\end{array}$ \\
\hline \multicolumn{7}{|c|}{ Flocculent layer } \\
\hline $\begin{array}{l}10 \text { May } \\
10 \text { May } \\
10 \text { May } \\
10 \text { May }\end{array}$ & $\begin{array}{l}\text { Neph. } \\
\text { Neph. } \\
\text { Over floc. } \\
\text { Over floc. }\end{array}$ & $\begin{array}{l}-1 \\
-1 \\
-1 \\
-1\end{array}$ & $\begin{array}{l}3.13(0.28) \\
3.83(0.35) \\
0.13(0.05) \\
0.08^{*}(0.05)\end{array}$ & $\begin{array}{l}1.50 \\
1.84 \\
0.06 \\
0.04\end{array}$ & & $\begin{array}{r}0.33 \\
0.27 \\
8.01 \\
13.02\end{array}$ \\
\hline
\end{tabular}




\section{Enrichment experiments}

Mean respiratory rates in the water enrichment experiments, averaged over all time points, were calculated on the original scale (Table 5). In the 1990 experiments, observations from triplicate vials of the same time and treatment combination were averaged, and the average values were used to calculate means and standard errors.

Table $4 .{ }^{3} \mathrm{H}$ leucine assimilation by natural microbial communities in Conception Bay, Newfoundland and the Avalon Channel east of Newfoundland, 1990. Where no standard error is shown, values are mean of duplicate measurements. Bacterial production (Simon \& Azam 1989) expressed as $\mathrm{mgC} \mathrm{m}^{-3} \mathrm{~d}^{-1}$; values integrated to estimate $\mathrm{mgC} \mathrm{m}^{-2} \mathrm{~d}^{-1}$. Data grouped by location, from offshore to the head of Conception Bay (Fig. 1). Mean \pm SE of all integrated values: $6.4 \pm 1.1$

\begin{tabular}{|c|c|c|c|c|c|c|}
\hline $\begin{array}{l}\text { Date } \\
(1990)\end{array}$ & $\begin{array}{l}\text { Depth } \\
(\mathrm{m})\end{array}$ & pmol l ${ }^{-1} h^{-1}$ & $\pm \mathrm{SE}$ & \multicolumn{2}{|c|}{$\begin{array}{c}\text { Bacterial production } \\
\left(\mathrm{mgC} \mathrm{m}^{-3} \mathrm{~d}^{-1}\right) \quad\left(\mathrm{mgC} \mathrm{m}^{-2} \mathrm{~d}^{-1}\right)\end{array}$} & Location \\
\hline 3 May & 24 & 1.1 & 0.35 & 0.08 & 2.17 & $48^{\circ} 07.4^{\prime} \mathrm{N}, 52^{\circ} 44.0^{\prime} \mathrm{W}$ \\
\hline 3 May & 150 & 0.02 & 0.01 & 0.002 & & $48^{\circ} 07.4^{\prime} \mathrm{N}, 52^{\circ} 44.0^{\prime} \mathrm{W}$ \\
\hline 3 May & 10 & 1.8 & - & 0.13 & 2.7 & $48^{\circ} 07.4^{\prime} \mathrm{N}, 51^{\circ} 12.4^{\prime} \mathrm{W}$ \\
\hline 3 May & 150 & 0.08 & - & 0.01 & & $48^{\circ} 07.4^{\prime} \mathrm{N}, 51^{\circ} 12.4^{\prime} \mathrm{W}$ \\
\hline 8 May & 10 & 1.23 & 0.13 & 0.09 & 6.4 & $47^{\circ} 42.4^{\prime} \mathrm{N}, 52^{\circ} 15.4^{\prime} \mathrm{W}$ \\
\hline 8 May & 25 & 3.3 & 0.03 & 0.25 & & $47^{\circ} 42.4^{\prime} \mathrm{N}, 52^{\circ} 15.4^{\prime} \mathrm{W}$ \\
\hline 8 May & 100 & 0.23 & 0.07 & 0.02 & & $47^{\circ} 42.4^{\prime} \mathrm{N}, 52^{\circ} 15.4^{\prime} \mathrm{W}$ \\
\hline 8 May & 172 & 0.04 & 0.01 & 0.003 & & $47^{\circ} 42.4^{\prime} \mathrm{N}, 52^{\circ} 15.4^{\prime} \mathrm{W}$ \\
\hline 3 May & 10 & 2.47 & - & 0.18 & 2.2 & $48^{\circ} 07.4^{\prime} \mathrm{N}, 52^{\circ} 05.9^{\prime} \mathrm{W}$ \\
\hline 3 May & 150 & 0.04 & - & 0.003 & & $48^{\circ} 07.4^{\prime} \mathrm{N}, 52^{\circ} 05.9^{\prime} \mathrm{W}$ \\
\hline 6 May & 25 & 1.53 & 0.10 & 0.11 & 6.0 & $47^{\circ} 49.9^{\prime} \mathrm{N}, 52^{\circ} 54.7^{\prime} \mathrm{W}$ \\
\hline 6 May & 100 & 0.39 & 0.04 & 0.03 & & $47^{\circ} 49.9^{\prime} \mathrm{N}, 52^{\circ} 54.7^{\prime} \mathrm{W}$ \\
\hline 6 May & 195 & 0.19 & 0.01 & 0.01 & & $47^{\circ} 49.9^{\prime} \mathrm{N}, 52^{\circ} 54.7^{\prime} \mathrm{W}$ \\
\hline 6 May & $257^{\circ}$ & 0.23 & 0.04 & 0.02 & & $47^{\circ} 41.1^{\prime} \mathrm{N}, 53^{\circ} 05.1^{\prime} \mathrm{W}$ \\
\hline 6 May & $249 t$ & 0.41 & 0.03 & 0.03 & & $47^{\circ} 41.1^{\prime} \mathrm{N}, 53^{\circ} 05.1^{\prime} \mathrm{W}$ \\
\hline $6 \mathrm{May}$ & $239 \pm$ & 0.23 & 0.03 & 0.02 & & $47^{\circ} 41.1^{\prime} \mathrm{N}, 53^{\circ} 05.1^{\prime} \mathrm{W}$ \\
\hline 2 May & 60 & 0.47 & - & 0.04 & 4.7 & $47^{\circ} 41.1^{\prime} \mathrm{N}, 53^{\circ} 05.1^{\prime} \mathrm{W}$ \\
\hline 2 May & 175 & 0.22 & - & 0.02 & & $47^{\circ} 41.1^{\prime} \mathrm{N}, 53^{\circ} 05.1^{\prime} \mathrm{W}$ \\
\hline 4 May & 10 & 1.65 & - & 0.12 & 1.5 & $47^{\circ} 55.3^{\prime} \mathrm{N}, 51^{\circ} 44.8^{\prime} \mathrm{W}$ \\
\hline $4 \mathrm{May}$ & 165 & 0.02 & - & 0.002 & & $47^{\circ} 55.3^{\prime} \mathrm{N}, 51^{\circ} 44.8^{\prime} \mathrm{W}$ \\
\hline 4 May & 10 & 2.50 & - & 0.19 & 2.8 & $47^{\circ} 55.3^{\prime} \mathrm{N}, 52^{\circ} 15.4^{\prime} \mathrm{W}$ \\
\hline 4 May & 180 & 0.06 & - & 0.005 & & $47^{\circ} 55.3^{\prime} \mathrm{N}, 52^{\circ} 15.4^{\prime} \mathrm{W}$ \\
\hline 19 May & 30 & 0.82 & 0.18 & 0.06 & 6.5 & $47^{\circ} 45.5^{\prime} \mathrm{N}, 52^{\circ} 57.6^{\prime} \mathrm{W}$ \\
\hline 19 May & 70 & 0.37 & 0.06 & 0.03 & & $47^{\circ} 45.5^{\prime} \mathrm{N}, 52^{\circ} 57.6^{\prime} \mathrm{W}$ \\
\hline 19 May & 150 & 0.55 & 0.02 & 0.04 & & $47^{\circ} 45.5^{\prime} \mathrm{N}, 52^{\circ} 57.6^{\prime} \mathrm{W}$ \\
\hline 6 May & 6 & 1.23 & 0.08 & 0.09 & 3.1 & $47^{\circ} 45.5^{\prime} \mathrm{N}, 52^{\circ} 57.6^{\prime} \mathrm{W}$ \\
\hline 6 May & 30 & -0.03 & 0.008 & 0 & & $47^{\circ} 45.5^{\prime} \mathrm{N}, 52^{\circ} 57.6^{\prime} \mathrm{W}$ \\
\hline 6 May & 120 & 0.21 & 0.06 & 0.02 & & $47^{\circ} 45.5^{\prime} \mathrm{N}, 52^{\circ} 57.6^{\prime} \mathrm{W}$ \\
\hline 6 May & 200 & 0.13 & 0.001 & 0.01 & & $47^{\circ} 45.5^{\prime} \mathrm{N}, 52^{\circ} 57.6^{\prime} \mathrm{W}$ \\
\hline 1 May & 6 & 1.27 & 0.001 & 0.09 & 6.7 & $47^{\circ} 45.5^{\prime} \mathrm{N}, 52^{\circ} 57.6^{\prime} \mathrm{W}$ \\
\hline $1 \mathrm{May}$ & 25 & 2.41 & 0.19 & 0.18 & & $47^{\circ} 45.5^{\prime} \mathrm{N}, 52^{\circ} 57.6^{\prime} \mathrm{W}$ \\
\hline 1 May & 125 & 0.31 & 0.06 & 0.02 & & $47^{\circ} 45.5^{\prime} \mathrm{N}, 52^{\circ} 57.6^{\prime} \mathrm{W}$ \\
\hline 1 May & 200 & 0.15 & 0.007 & 0.01 & & $47^{\circ} 45.5^{\prime} \mathrm{N}, 52^{\circ} 57.6^{\prime} \mathrm{W}$ \\
\hline $18 \mathrm{Apr}$ & 16 & 7.12 & 0.38 & 0.53 & 14.4 & $47^{\circ} 32.2^{\prime} \mathrm{N}, 53^{\circ} 07.9^{\prime} \mathrm{W}$ \\
\hline $18 \mathrm{Apr}$ & 100 & 1.00 & 0.12 & 0.07 & & $47^{\circ} 32.2^{\prime} \mathrm{N}, 53^{\circ} 07.9^{\prime} \mathrm{W}$ \\
\hline 2 May & 25 & 0.51 & 0.08 & 0.04 & 7.1 & $47^{\circ} 32.2^{\prime} \mathrm{N}, 53^{\circ} 07.9^{\prime} \mathrm{W}$ \\
\hline 2 May & 100 & 0.41 & 0.14 & 0.03 & & $47^{\circ} 32.2^{\prime} \mathrm{N}, 53^{\circ} 07.9^{\prime} \mathrm{W}$ \\
\hline 2 May & 175 & -0.02 & 0.03 & 0 & & $47^{\circ} 32.2^{\prime} \mathrm{N}, 53^{\circ} 07.9^{\prime} \mathrm{W}$ \\
\hline 2 May & $238^{\circ}$ & 0.70 & 0.41 & 0.05 & & $47^{\circ} 32.2^{\prime} \mathrm{N}, 53^{\circ} 07.9^{\prime} \mathrm{W}$ \\
\hline 2 May & $230 t$ & 1.14 & 0.22 & 0.08 & & $47^{\circ} 32.2^{\prime} \mathrm{N}, 53^{\circ} 07.9^{\prime} \mathrm{W}$ \\
\hline 2 May & 220 & 0.35 & 0.09 & 0.03 & & $47^{\circ} 32.2^{\prime} \mathrm{N}, 53^{\circ} 07.9^{\prime} \mathrm{W}$ \\
\hline $24 \mathrm{Apr}$ & 18 & 5.34 & 0.49 & 0.39 & 7.8 & $47^{\circ} 32.2^{\prime} \mathrm{N}, 53^{\circ} 07.9^{\prime} \mathrm{W}$ \\
\hline $24 \mathrm{Apr}$ & 100 & 0.19 & 0.05 & 0.01 & & $47^{\circ} 32.2^{\prime} \mathrm{N}, 53^{\circ} 07.9^{\prime} \mathrm{W}$ \\
\hline 29 Apr & 30 & 3.15 & 0.3 & 0.23 & & $47^{\circ} 32.2^{\prime} \mathrm{N}, 53^{\circ} 07.9^{\prime} \mathrm{W}$ \\
\hline $29 \mathrm{Apr}$ & 90 & 0.90 & 0.04 & 0.07 & & $47^{\circ} 32.2^{\prime} \mathrm{N}, 53^{\circ} 07.9^{\prime} \mathrm{W}$ \\
\hline $30 \mathrm{Apr}$ & 30 & 2.86 & 0.32 & 0.21 & 17.1 & $47^{\circ} 32.2^{\prime} \mathrm{N}, 53^{\circ} 07.9^{\prime} \mathrm{W}$ \\
\hline $30 \mathrm{Apr}$ & 90 & 2.41 & 0.59 & 0.18 & & $47^{\circ} 32.2^{\prime} \mathrm{N}, 53^{\circ} 07.9^{\prime} \mathrm{W}$ \\
\hline
\end{tabular}


Table 5. Mean respiratory rates ( $\mu \mathrm{g}$ atoms $\mathrm{O}^{-1} \mathrm{~d}^{-1} \pm 2 \mathrm{SE}$ ) of water samples enriched with glucose and proteose-peptone substrates and incubated at the temperatures shown. Samples were taken for measurement at intervals of 1 to $2 \mathrm{~d}$ over 10 to $14 \mathrm{~d}$. Means calculated across time points. Where only 1 or 2 groups of replicate samples are included in a time series, no standard error is calculated

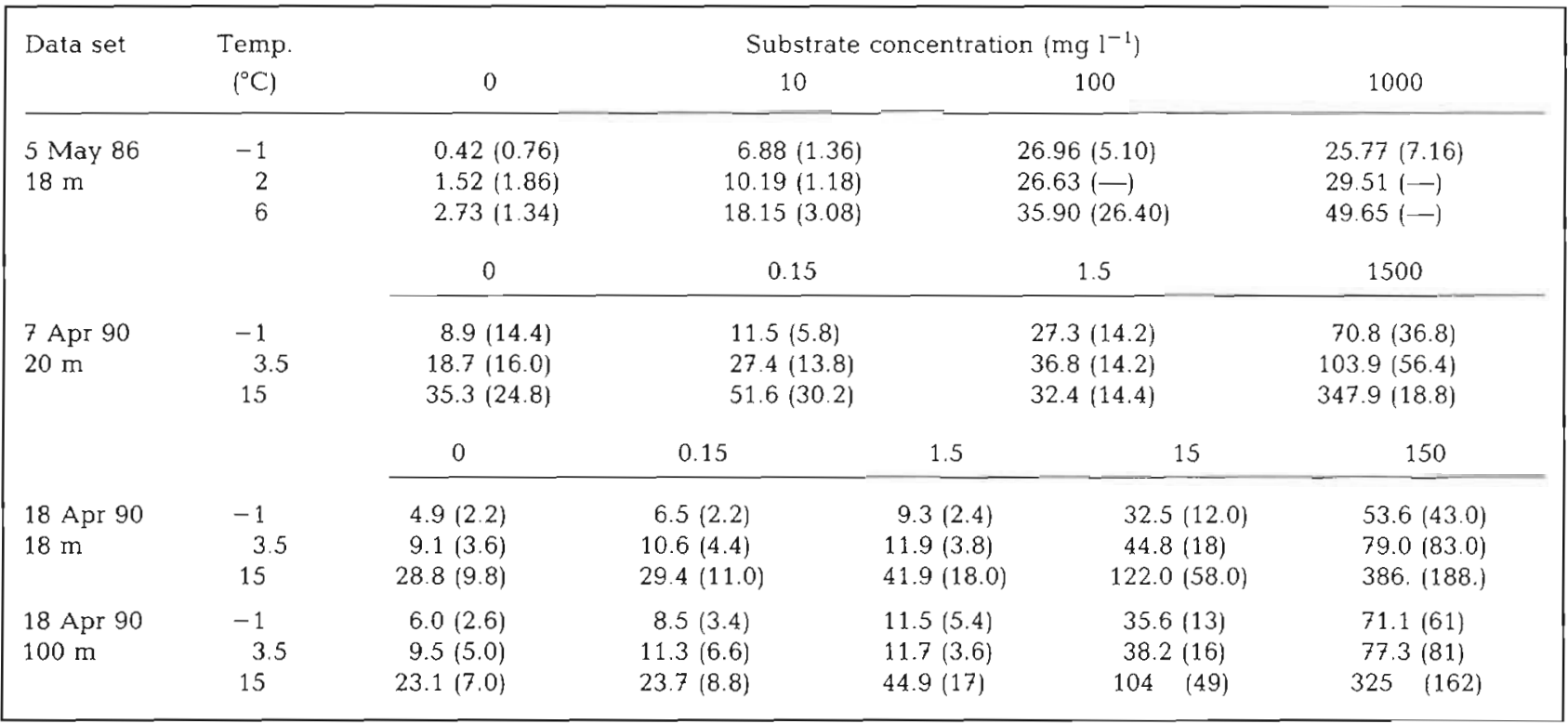

In the 1986 experiment, there were significant effects due to temperature $(\mathrm{p}=0.0013)$ and substrate concentration ( $p=0.0001$ ). The interaction between temperature and substrate concentration yielded a $p$ value of 0.078 , suggesting possible significance. In the experiment begun April 7, 1990 there were significant effects due to temperature $(p=0.001)$ and substrate concentration ( $\mathrm{p}=0.001)$, but no significant interaction between temperature and substrate concentration $(p=0.39)$. In the 2 experiments beginning April 18, 1990 there were significant effects due to temperature and substrate concentration, but significant temperature-substrate interactions were found only at the lowest substrate concentrations. The interaction of temperature and substrate concentration is illustrated graphically in Fig. 5. At $-1{ }^{\circ} \mathrm{C}$, and with only the naturally present substrate concentration, water from the chlorophyll maximum at $18 \mathrm{~m}$ showed no significant utilization of oxygen in the dark after $2 \mathrm{wk}$. At that temperature, only additions of 15 $\mathrm{mg} \mathrm{l}^{-1}$ proteose-peptone resulted in significant respiratory oxygen utilization. At $3.5^{\circ} \mathrm{C}$, oxygen depletion at the higher substrate concentrations was more rapid than at $-1^{\circ} \mathrm{C}$, but at the lower substrate concentrations oxygen utilization could not be discerned. However, at $15^{\circ} \mathrm{C}$, there was significant, linear oxygen utilization even without added substrate.

\section{Benthic utilization of bloom fallout}

The benthic lander data permit us to estimate both aerobic and anaerobic utilization of fallout from the diatom bloom by the benthos. These data are of further interest in that this was the first time measurements have been made in situ at this temperature in coastal waters, and especially that the rates proved to be significant (Table 6). Benthic aerobic respiration, based on the depletion of oxygen under the bell jars, was $2 \%$ of a time-weighted mean of our estimates of photosynthesis during the early spring bloom and $20 \%$ of photosynthesis during the late bloom period, with $95 \%$ confidence limits of about $\pm 20 \%$ for the set of 3 deployments of the lander vehicle. The rate of anaerobic respiration in the sediments can be estimated by comparison of the oxygen demand and the rates of remineralization of $\mathrm{N}$. Using the Redfield ratio (C:N:P $=106: 16: 1)$ as a model of the stoichiometry of remineralization, the deficit of remineralized $\mathrm{NO}_{3}$ is equivalent to $10.8 \mathrm{mg} \mathrm{C} \mathrm{m}^{-2} \mathrm{~d}^{-1}$. If one uses the estimate of benthic respiration from the benthic lander of $107 \mathrm{mg} \mathrm{C} \mathrm{m}^{-2} \mathrm{~d}^{-1}$ and adds it to the estimated 10.8 $\mathrm{mg} \mathrm{C} \mathrm{m} \mathrm{m}^{-2} \mathrm{~d}^{-1}$ from denitrification, plus the water column bacterial praduction of $23 \mathrm{mg} \mathrm{C} \mathrm{m}^{-2} \mathrm{~d}^{-1}$, plus an equal amount for bacterial respiration, the total is 164 $\mathrm{mg} \mathrm{C} \mathrm{m}{ }^{-2} \mathrm{~d}^{-1}$. That is $3 \%$ of the mean primary production rate during the early bloom and $33 \%$ of the mean primary production rate during the late bloom. If we assume the bacteria in the water column to be only $10 \%$ efficient instead of the more conventional $50 \%$, the total organic carbon consumption will be $348 \mathrm{mg} \mathrm{C}$ $\mathrm{m}^{-2} \mathrm{~d}^{-1}$, which will consume $7 \%$ of total primary production during the early bloom and $68 \%$ of the late bloom. 


\section{DISCUSSION}

\section{Bacterial biomass and production}

The numbers of free-living heterotrophic bacteria in Conception Bay and Newfoundland coastal waters during the spring bloom were at the low end of the range reported in the ocean (Sorokin 1978, Fuhrman \& Azam 1980, Hanson et al. 1983). The 1990 mean was $2.7 \times 10^{5}$ cells $\mathrm{ml}^{-1}$, slightly lower than the mean reported for oligotrophic ocean water by Cho \& Azam (1990). Estimates of bacterial growth based on assimilation of ${ }^{3} \mathrm{H}$ leucine in the upper mixed layer were $63 \pm 11.6 \mathrm{~d}$ (mean $\pm 1 \mathrm{SE}$ ) and at all depths $390 \pm 96 \mathrm{~d}$. Estimates of bacterial growth based on the assimilation of tritiatied thymidine indicated a mean doubling time of $30 \pm$ $12 \mathrm{~d}(\mathrm{n}=20)$, using only the significant rates. If a value of $300 \mathrm{~d}$ was assumed for the non-significant rates, turnover was estimated to be $86 \pm 24 \mathrm{~d}(\mathrm{n}=25)$. Estimates of bacterial production, based on the frequency of dividing cells, using a log-transformed regression (Newell \& Christian 1981), based on the data of Hanson et al. (1983) from the Drake Passage, suggested a median doubling time of $1 \mathrm{mo}$, with a range of 14 to $40 \mathrm{~d}$. These results could mean a generally low growth rate or that only a small part of the population was actively growing. However, dividing cells were present in all morphotypes. Numbers of bacteria remained low, even when doubling times in the chlorophyll maximum layer were less than $1 \mathrm{~d}$. The high range of rates and their vertical distribution suggests transitory zones or layers of normal microbial loop activity in an otherwise microbially sluggish system. The results of studies of protozoan and tunicate grazing will be reported elsewhere.

Bacterial numbers are not usually low in a highly eutrophic system, but Conception Bay in April and May is in a eutrophic state. Rates of photosynthesis are high, as is standing stock of chlorophyll. If we plot Conception Bay bacterial abundance vs chlorophyll, the values fall at the very bottom of the envelope of world observations (cf. Fig. 1 of Cho \& Azam 1990). Following Cho \& Azam we plotted bacterial organic carbon/phytoplankton carbon vs chlorophyll, assuming $20 \mathrm{fgC} \mathrm{cell}^{-1}$ for bacteria and estimating phytoplankton carbon as chlorophyll $a \times 10$, based on data of Eppley et al. (1977) for diatom blooms. The resulting plot shows that almost all of our data fall in the $<1$ eutrophic range. No April values are $>1$. The 2 values significantly $>1$ are from the upper $20 \mathrm{~m}$ during May. Other May values fall near or below 1. Moreover, if we calculate phytoplankton carbon using the factor chlorophyll a $\times 50$, as Cho \& Azam did, all except one of our values become $<1$. Thus, Conception Bay and the Avalon Channel region of the continental shelf are eutrophic during the spring
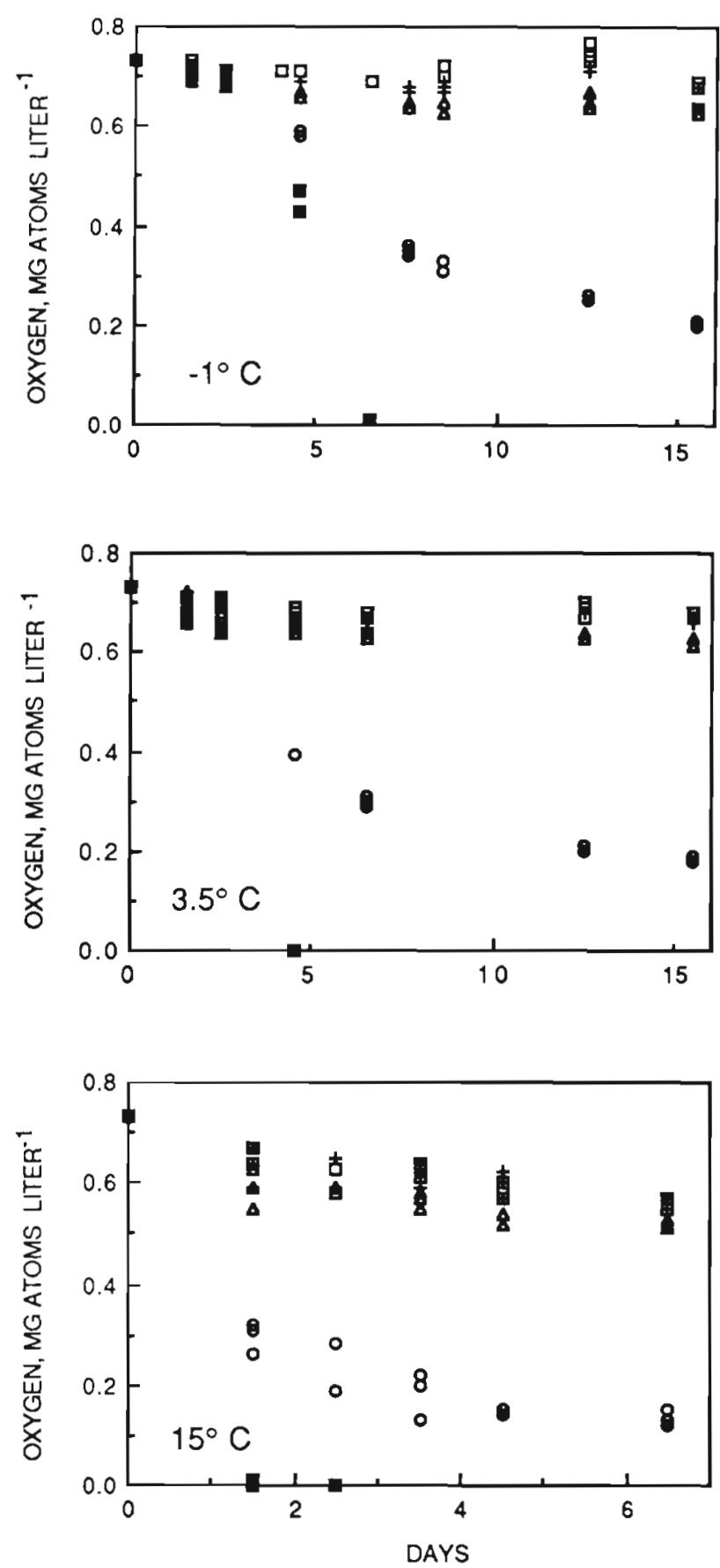

Fig. 5. Changes in dissolved oxygen ( $\mathrm{mg}$ atoms $\mathrm{Ol}^{-1}$ ), in water collected at $16 \mathrm{~m}$ on 18 April 1990 at the sediment trap mooring station in Conception Bay, Newfoundland $\left(47^{\circ} 32.2^{\prime} \mathrm{N}, 53^{\circ} 07.9^{\prime} \mathrm{W}\right)$ and enriched with 4 different concentrations of proteose-peptone substrate. Results at 3 incubation temperatures are shown. There are 3 replicates of each substrate concentration at every sampling time, but many of the symbols overlap. In the $15^{\circ} \mathrm{C}$ incubation, oxygen was being depleted rapidly during the experiment, which was terminated after $6 \mathrm{~d}$. Temperature at $18 \mathrm{~m}$ from the CTD cast at the time of collection was $-0.1^{\circ} \mathrm{C}$. Amounts of added substrate $\left(\mathrm{mg} \mathrm{l}^{-1}\right)$ : (ם) $0,(+) 0.15,(\Delta) 1.5$, (O) 15 , (a) 150 
bloom, with very low bacterial biomass relative to phytoplankton biomass.

The regular appearance of significant numbers of crescent (and ring) shaped cells, although not unprecedented, deserves mention. These bacteria most likely belong to the family Spirosomaceae and the genus Cyclobacterium. As reviewed by Raj \& Moloy (1990a, b), the genus is marine; it has been isolated from $4{ }^{\circ} \mathrm{C}$ water near a thermal vent and as an epibiont on Homarus americanus eggs and on the Pacific coast sand dollar. Hauxhurst et al. (1980) isolated 10 psychrophilic strains from the Gulf of Alaska which appeared morphologically similar to Cyclobacterium marinus, the type species, but differed significantly from it in physiology and biochemistry. These strains were lost before they could be classified. Sieburth (1975) showed morphologically similar organisms as epibionts on algae, mangrove leaves, and seagrass blades. Schmaljohan (1984) described a similar morphotype in the Baltic Sea, Kattegat und Skagerrak that in many locations constituted over $20 \%$ of the total bacteria in direct counts. He also noted that they have been observed in Antarctic waters, off Portugal in coastal waters, and in the European Mediterranean. There is, unfortunately, little information as to their role in nature, but given the diversity of locations in which they occasionally have been noted, further work on this group should be rewarding.

Recently, the conversion of thymidine uptake to estimates of bacterial growth has been criticized on several grounds as being inaccurate (Pollard \& Moriarty 1984, Chin-Leo \& Kirchman 1988, Chrzanowski 1988, Hollibaugh 1988, Karl 1986). Nevertheless, the present data set consists of generally low rates and indeed rates too low to be measured over $12 \mathrm{~h}$ in many cases. We conclude that bacterial growth during the spring bloom in Conception Bay was very low much of the time, resulting in little conversion of organic carbon into bacterial biomass. Using the thymidine-to-carbon conversion factor suggested by Bell (1990) and inter- polating between depths, mean water column production of hetrotrophic bacteria during the spring bloom was $13.6 \mathrm{mg} \mathrm{C} \mathrm{m}^{-2} \mathrm{~d}^{-1}(\mathrm{n}=10)$. Assuming an assimilation efficiency of $33 \%$, which is representative of values reported from cold waters (Morita et al. 1977, Pomeroy et al. 1990), water column utilization of organic carbon by heterotrophic bacteria is on the order of $41 \mathrm{mg} \mathrm{C} \mathrm{m} \mathrm{m}^{-2} \mathrm{~d}^{-1}$. This is equivalent to about $0.8 \%$ of estimated net primary production during the early bloom and $8 \%$ during late bloom. Most previous studies in coastal waters and the upper mixed layer of the ocean suggest bacterial production on the order of 25 to $50 \%$ of primary production (Fuhrman \& Azam 1980, Williams 1984, McManus \& Peterson 1988). In McMurdo Sound, Fuhrman \& Azam (1980) found a wide range of rates. One side of McMurdo Sound is oligotrophic, with rates like those we found in Conception Bay, while the other is more eutrophic (Hodson et al. 1981). Sullivan et al. (1990) estimated bacterial production to be $11 \%$ of primary production in an antarctic marginal ice zone. In Conception Bay, significant bacterial production is limited to the region of the chlorophyll maximum, usually within the upper $30 \mathrm{~m}$ Thus, there can be a thin stratum of significant bacterial production, but even if it is present, it is consuming only a small fraction of total primary production. In one exceptional set of observations on 15 April 1988 in which rates throughout the mixed layer were high, we estimated total bacterial production of $33.8 \mathrm{mg} \mathrm{C} \mathrm{m}^{-2}$ $\mathrm{d}^{-1}$. Correcting for estimated efficiency, utilization of organic carbon is $264 \mathrm{mg} \mathrm{C} \mathrm{m} \mathrm{d}^{-1}$. This value approaches the usual expectation in warmer water (Ducklow \& Hill 1985, Fuhrman et al. 1985, 1989, Pomeroy et al. 1987) and affirms that bursts of microbial activity occur in Conception Bay, as in cold water everywhere, albeit more restricted in space and time than in warmer water. Similar observations are reported in polar cold water, with high rates near shore (Hodson et al. 1981) or near melting sea ice (Smith et al. 1989, Cota et al. 1990). Evaluating our thymidine

Table 6. Data from deployments of a benthic free lander in Conception Bay, Newfoundland. Oxygen demand and nutrient flux $\left(\mu \mathrm{M} \mathrm{m}^{-2} \mathrm{~h}^{-1}\right) . \Sigma \mathrm{N}=$ sum of ammonium, nitrite, nitrate, and urea. Parenthetical values = standard deviation, number of replicates

\begin{tabular}{|c|c|c|c|c|c|c|c|c|c|c|}
\hline $\begin{array}{l}\text { Date } \\
\text { (1990) }\end{array}$ & Location & $\begin{array}{l}\text { Hours } \\
\text { down }\end{array}$ & $\begin{array}{l}\text { Oxygen } \\
\text { demand }\end{array}$ & $\mathrm{NH}_{4}$ & $\mathrm{NO}_{3}$ & $\mathrm{NO}_{2}{ }^{\mathrm{N}}$ & $\begin{array}{l}\text { trient flu } \\
\text { Urea }\end{array}$ & $\Sigma N$ & $\mathrm{PO}_{4}$ & $\mathrm{Si}(\mathrm{OH})_{4}$ \\
\hline 2 May & $\begin{array}{l}47^{\circ} 32.2^{\prime} \mathrm{N} \\
53^{\circ} 07.9^{\prime} \mathrm{W}\end{array}$ & 15 & 344 & $\begin{array}{l}131 \\
(6.5,4)\end{array}$ & $\begin{array}{l}2.9 \\
(6.2,4)\end{array}$ & $\begin{array}{l}0.6 \\
(0.6,4)\end{array}$ & $\begin{array}{l}2.9 \\
(6.2,4)\end{array}$ & 137 & $\begin{array}{l}7.6 \\
(6.6,4)\end{array}$ & $\begin{array}{l}220 \\
(143,4)\end{array}$ \\
\hline 4 May & $\begin{array}{l}47^{\circ} 07.9^{\prime} \mathrm{N} \\
53^{\circ} 05.1^{\prime} \mathrm{W}\end{array}$ & 36 & 304 & $\begin{array}{l}4.3 \\
(2.9,4)\end{array}$ & $\begin{array}{l}1.2 \\
(2.8,4)\end{array}$ & $\begin{array}{l}0.03 \\
(0.05,4)\end{array}$ & $\begin{array}{l}0.17 \\
(1.1,4)\end{array}$ & 5.7 & $\begin{array}{l}1.3 \\
(0.7,4)\end{array}$ & $\begin{array}{l}92 \\
(28,4)\end{array}$ \\
\hline 5 May & $\begin{array}{l}47^{\circ} 32.2^{\prime} \mathrm{N} \\
53^{\circ} 07.9^{\prime} \mathrm{W}\end{array}$ & 15 & - & $\begin{array}{l}25.0 \\
(2.8,3)\end{array}$ & $\begin{array}{l}13.0 \\
(7.0,3)\end{array}$ & $\begin{array}{l}0.05 \\
(0.18,3)\end{array}$ & $\begin{array}{l}1.6 \\
(2.2,3)\end{array}$ & 39.6 & $\begin{array}{l}6.0 \\
(0.9,3)\end{array}$ & $\begin{array}{l}187 \\
(35,3)\end{array}$ \\
\hline 7 May & $\begin{array}{l}47^{\circ} 07.9^{\prime} \mathrm{N} \\
53^{\circ} 05.1^{\prime} \mathrm{W}\end{array}$ & 15 & $\begin{array}{c}402 \\
\{0.056\}\end{array}$ & $\begin{array}{l}23.5 \\
(10.6)\end{array}$ & $\begin{array}{l}4.0 \\
(7.8)\end{array}$ & $\begin{array}{l}0.8 \\
(0.9,3)\end{array}$ & $\begin{array}{l}1.7 \\
(1.6,3)\end{array}$ & 30 & $\begin{array}{l}8.2 \\
(5.1)\end{array}$ & $\begin{array}{l}194 \\
(50.6)\end{array}$ \\
\hline Mean & & & 350 & 46 & 5.3 & 0.4 & 1.6 & 53 & 5.6 & 173 \\
\hline
\end{tabular}


assimilation data as a whole, depth ( $\log _{10}$ transform) explains $70 \%$ of the variance, while temperature explains $19 \%$, suggesting more favorable conditions in the chlorophyll maximum layer for bacterial production. Since there is probably a higher concentration of labile substrates in the chlorophyll maximum than in most of the remainder of the water column below it, the correlation with depth really reflects the distribution of substrates.

Bacterial production estimates based on assimilation of leucine (Simon \& Azam 1989) were somewhat lower than those based on assimilation of thymidine. However, since the data were taken in separate years $(1990$ and 1988 respectively), it is not possible to evaluate whether this represents real year-to-year differences or a consistent trend in that environment. Our estimates of dissolved free leucine in the water during the Newfoundland spring bloom by isotope dilution are comparable to the lowest concentrations found by HPLC analysis during the spring bloom in the Drake Passage and Gerlache Strait (Haberstroh et al. 1988). In some phytoplankton-rich waters much higher concentrations have been observed (Bohling 1970, Schell 1974, Billen et al. 1980), but these were systems with substantial grazing zooplankton populations.

\section{Bacterial respiration}

Just as we can find reports of a wide range of rates of bacterial growth, there are reports of respiratory rates up to or exceeding rates of primary production (Pomeroy \& Johannes 1968, Lucas et al. 1986, Pomeroy \& Deibel 1986, Smith et al. 1986, Hopkinson et al. 1989, Griffith et al. 1990). Smith et al. (1986) measured respiratory rate (by precision Winkler titration) and bacterial production (by serial direct counts) on the productive outer edge of the Grand Banks during the spring bloom and concluded that while bacteria were not growing significantly they were respiring at a rate approximately equivalent to the rate of primary production. Smith et al. recognized that if this were true, little primary production would remain to support the metazoan food web. Our sediment trap data (to be reported in detail elsewhere) show that a significant fraction of the diatom bloom in Conception Bay sank to the bottom. So, although we lack a precise measure of in situ respiratory rate in Conception Bay, the empirical evidence from sediment traps suggests that the rate should be less than the rate of photosynthesis, unless there is some allochthonous source of substrate. We infer from our measurements of bacterial production that brief periods of microbial metabolic activity occur, usually limited to a relatively thin lens of water, interspersed with extended periods of much reduced activ- ity. Once the surface water becomes $>5^{\circ} \mathrm{C}$, in June and thereafter, we assume that the microbial loop is active in that layer, although primary production is then low.

High respiratory rate in the absence of significant bacterial growth, as reported by Smith et al. (1986) and Griffith et al. (1990), indicates very low assimilation efficiency. Bacterial assimilation efficiency may be controlled by factors other than the quantity of available substrates. Efficiency may be influenced by refractory substrates (Moran \& Hodson 1990) or by the C:N ratio of substrates. Linley \& Newell (1984) and Hopkinson et al. (1989) modeled bacterial growth efficiency in relation to the $\mathrm{C}: \mathrm{N}$ ratio of available substrates, showing that as the $C: N$ ratio increased, bacterial efficiency decreased. If heterotrophic bacteria are using substrates with a high $\mathrm{C}: \mathrm{N}$ ratio, they must make up their nitrogen requirements from inorganic sources. New nitrogen in the form of nitrate in the incoming Labrador Current water supports the phytoplankton bloom, and it may be utilized directly by bacteria only if they have depleted available dissolved amino acids and ammonium (Kirchman 1990), but with additional cost to assimilation efficiency. So we can postulate conditions in which bacterial growth yield may be low in Newfoundland coastal waters, but we are unable to evaluate efficiency during the spring bloom from the available data. This is a significant residual question.

\section{Benthic utilization of the bloom}

Bacterial production rates, on a volume basis, at $-1^{\circ} \mathrm{C}$ in the epibenthic flocculent layer, were lower than the rates found in sediment trap material at the same temperature, suggesting that material reaching the bottom had been processed quickly by the benthos. We lacked the data necessary to compare flocculent layer and sediment trap activities on a carbon or mass basis, but the implication from the bacterial production data was supported by microscopic examination. The flocculent layer consisted of amorphous gray fluff with little remaining plant pigment (pigment analyses to be reported elsewhere). The fluff contained many large bacteria not seen in the water column. It is possible that the bacteria were derived from populations in the sediments (e.g. Wainright 1990). We cannot discern, on the basis of our present observations, whether most of the fallout from the spring bloom was utilized directly by the benthic macrofauna and epibenthic zooplankton, or buried in the sediments by them. Nor can we tell whether there were bursts of bacerial acitivity as well. A. Redden (pers. com.) reports uniform chlorophyll a concentrations in the sediments to a depth of $10 \mathrm{~cm}$. Reichardt (1987) and Nedwell (1989) also noted burial 
of whole algal material in Antarctic sediments and both authors suggested it was the result of bioturbation. The benthic aerobic respiratory rate was equivalent to a carbon oxidation rate of $101 \mathrm{mg} \mathrm{C} \mathrm{m}^{-2} \mathrm{~d}^{-1}$ (Table 6). which is ca $2 \%$ of our mean of estimates of photosynthesis at the sediment trap station during the early bloom and $20 \%$ of photosynthesis during the late bloom. The rate is high compared to deep-sea measurements at an equivalent temperature (Rowe et al. 1990), but not considering the amounts of organic matter in the sediments $(3.4 \pm 0.3 \%$; Ostrom \& Macko in press). The rate is comparable to that reported by Wassman (1984) in Fanafjorden, Norway, which has a similar or somewhat higher sediment organic content and a bottom temperature of $6^{\circ} \mathrm{C}$.

\section{Overall utilization of the bloom}

While our estimates of microbial loop activity are speculative, they suggest that considerable primary production is not oxidized quickly, especially in the water column during the initial phase of the bloom. It is important to emphasize that zooplankton grazing is minimal during the Newfoundland spring bloom. Except in the terminal phase of the exceptionally long bloom of 1988 , fecal pellets were rare in the sediment trap collections. During the bloom, trap collections consisted largely of intact, red-fluorescing diatoms and aggregates of diatoms. Detailed data on zooplankton and sediment trap results will be reported elsewhere. Similar results were reported by Andersen (1988) from the Bering Sea, where microorganisms consumed $64 \%$ of the primary production in oligotrophic areas but only $5 \%$ in eutrophic, diatom-dominated areas. The small impact of zooplankton grazing on the bloom also results in little production of bacterial substrates through zooplankton metabolism, feeding, and defecation. Production of dissolved substrates by phytoplankton alone is insufficient to support the high levels of bacterial activity that are widely reported in the ocean (Smetacek \& Pollehne 1986). If we compare bacterial production, estimated from our $1988{ }^{3} \mathrm{H}$-thymidine incorporation values, with 1988 net primary production values, all values fall well below the $95 \%$ confidence envelope of the global relationship of bacterial production to primary production reported by Cole et al. (1988). In fact, our values fall even farther below the $95 \%$ confidence envelope than those reported from the Weddell Sea by Cota et al. (1990). Taking our 1988 observations as a group, there is so significant correlation between bacterial production and net primary production $\left(\mathrm{r}^{2}=0.002\right)$.

Several authors have reported observations which, they say, conflict with the report of Pomeroy \& Deibel
(1986) that microbial loop activity at $-1{ }^{\circ} \mathrm{C}$ was reduced relative to photosynthetic rates during the 1984-85 Newfoundland spring blooms. At the time of that publication, evidence of the interaction between temperature and substrate concentration was lacking, with the result that these reports do not address that aspect of the problem. Li \& Dickie (1987) reported no differential between the effects of temperature on photosynthesis and bacterial production in Bedford Basin, Nova Scotia, a eutrophic embayment with bacterial numbers in excess of $10^{6} \mathrm{ml}^{-1}$ at all times and water temperature higher than that of Conception Bay. Although we might not expect to see in Bedford Basin the kind of temperature-substrate effect we found in Conception Bay, it is interesting that the lowest and most uniform numbers of bacteria in Bedford Basin do occur at the annual temperature minimum, coinciding with the onset of the spring bloom. Bird \& Karl (1988) measured incorporation of tritiatied thymidine and glutamic acid as parameters of microbial loop activity in Bransfield Strait, Antarctica, and reported no direct effect of temperature on rates of uptake. However, they developed a model which relates glutamic acid uptake, a parameter of heterotrophic bacterial activity, to concentrations of particulate phaeopigment and particulate DNA in the water. Phaeopigment is well known as an indicator of zooplankton grazing activity and in this case may be correlated with the concentration of dissolved substrates available to bacteria. Haberstroh et al. (1987) measured dissolved amino acids in Bransfield Strait and Drake Passage, finding micromolar concentrations of total DFAA as deep as $200 \mathrm{~m}$ in Bransfield Strait and down to $40 \mathrm{~m}$ in the Drake Passage. If the results of our enrichment experiments have general applicability, we would not expect to see a strong correlation of microbial loop with temperature at such high concentrations of bacterial substrates. These 2 examples illustrate the problem of separating temperature and substrate as limitations of bacterial metabolism or growth and point to the need for attention to both factors in evaluating the limits to microbial loop activity. This leads us to postulate a limit to bacterial growth at low temperature at the cellular level, such as a physico-chemical limit to membrane permeability, limited temperature ranges of enzyme activity, or a combination of both.

Acknowledgements. This report results from the Cold Ocean Productivity Experiment, an international research program supported in part by US National Science Foundation grant OCE 8709809 to L.R.P. and W.J.W., and by a Strategic Grant to D. Deibel et al. from the Natural Sciences and Engineering Research Council of Canada. We thank R. Haedrich and D Idler, present and former Directors, Ocean Sciences Centre, Memorial University of Newfoundland, for their support of many aspects of this work, including travel support for the benthic lander project. We also thank the diving support group, O.S.C. for assistance on RV 'Karl and Jackie II' and the 
officers and crew of C.S.S. 'Baffin' and R. V 'Shamook' for assistance. Peter Schwinghamer provided samples of the flocculent layer. Barry Hargrave provided helpful advice on sediment trap design. Contribution No. 124 of the Ocean Sciences Centre.

\section{LITERATURE CITED}

Andersen, P. (1988). The quantitative importance of the 'microbial loop' in the marine pelagic: a case study from the North Bering/Chukchi Seas. Arch. Hydrobiol. Beih. Ergebn. Limnol. 31: 243-351

Andrews, P., Williams, P. J. leB. (1971). Heterotrophic utilisation of dissolved organic compounds in the sea. III. Measurement of the oxidation rates and concentrations of glucose and amino acids in seawater. J. mar. biol. Ass. U. K. 51: $111-126$

Azam, F., Fenchel, T., Field, J. G., Gray, J.-S., Meyer-Reil, L. A., Thingstad F. (1983). The ecological role of water column microbes in the sea. Mar. Ecol. Prog. Ser. 10: 157-263

Bell, R. T. (1990). An explanation for the variability in the conversion factor deriving bacterial cell production from incorporation of $\left[{ }^{3} \mathrm{H}\right]$ thymidine. Limnol. Oceanogr. 35: 910-915

Billen, G., Joiris, C., Wijnant, J., Gillain, G. (1980). Concentration and microbial utilization of small organic molecules in the Scheldt estuary, the Belgian coastal zone of the North Sea and the English Channel. Estuar. coast. mar. Sci. 11: 279-294

Bird, D. F., Karl, D. M. (1988). Microbial incorporation of exogenous thymidine and glutamic acid in surface waters of the Bransfield Strait: a RACER analysis. Antarctic J. U.S. 23 (5): 119-120

Bohling, H. (1970). Untersuchungen über freigelösten Aminosäuren im Meerwasser. Mar. Biol. 6: 213-225

Burney, C. M., Davis, P. G., Johnson, K. M., Sieburth, J. McN. (1982). Diel relationships of microbial trophic groups and in situ dissolved carbohydrate dynamics in the Caribbean Sea. Mar. Biol, 67: 311-322

Chin-Leo, G., Kirchman, D. L. (1988). Estimating bacterial production in marine waters from the simultaneous incorporation of thymidine and leucine. Appl. environ. Microbiol. 54: 1934-1939

Cho, B. C., Azam, F. (1990) Biogeochemical significance of bacterial biomass in the ocean's euphotic zone. Mar. Ecol. Prog. Ser. 63: 253-259

Chrzanowski, T. H. (1988). Consequences of accounting for isotopic dilution in thymidine incorporation assay. Appl environ. Microbiol. 54: 1868-1870

Cole, J. J., Findlay, S., Pace, M. L. (1988). Bacterial production in fresh and saltwater ecosystems: a cross-system overview. Mar. Ecol. Prog. Ser. 43: 1-10

Cota, G. F., Kottmeier, S. T., Robinson, D. H. Smith, W. O., Jr Sullivan, C. W. (1990). Bacterioplankton in the marginal ice zone of the Weddell Sea: biomass, production and metabolic activities during austral autumn. Deep-Sea Res. 37: 1145-1167

Douglas, D. J., Novitsky, J. A., Foumier, R. O. (1987). Microautoradiography-based enumeration of bacteria with estimates of thymidine-specific growth and production rates. Mar. Ecol. Prog. Ser. 36: 91-99

Ducklow, H. W., Hill, S. M. (1985). The growth of heterotrophic bacteria in the surface waters of warm core rings Limnol. Oceanogr. 30: 239-259

Eppley, R. E., Harrison, W. G., Chisholm, S. W., Stewart, E
(1977). Particulate organic matter in surface waters off Southern California and its relationship to phytoplankton. J. mar. Res. 35: 671-696

Fuhrman, J., Azam, F. (1980). Bacterioplankton secondary production estimates for coastal waters of British Columbia, Antarctica, and California. Appl. environ. Microbiol. 39: 1085-1095

Fuhrman, J. A., Ferguson, R. L. (1986) Nanomolar concentrations and rapid turnover of dissolved free amino acids in seawater agreement between chemical and microbiological measurements. Mar. Ecol. Prog. Ser. 33: 237-242

Fuhrman, J. A., Eppley, R. W., Hagström, A., Azam, F. (1985). Diel variations in bacterioplankton, phytoplankton, and related parameters in the Southern California Bight. Mar Ecol. Ser. 27: 9-20

Fuhrman, J. A., Sleeter, T. D., Carlson, C. A., Proctor, L. M. (1989). Dominance of bacterial biomass in the Sargasso Sea and its ecological implications. Mar. Ecol. Prog. Ser 57: 207-217

Griffith, P. C., Douglas, D. J., Wainright, S. C. (1990). Metabolic activity of size-fractionated microbial plankton in estuarine, nearshore, and continental shelf waters of Georgia. Mar. Ecol. Prog. Ser. 59: 263-270

Haberstroh, P. R., Bailiff, M. D., Tien, G., Taylor, G. T., Jones, D. Tilbrook, B., Nawrocki, M., Karl, D. M. (1987). RACER dissolved free amino acid concentrations, molecular composition and microbial uptake rates in the Bransfield Strait Antarctic J. U. S. 22: 153-156

Hanson, R. B., Shafer, D., Ryan, T., Pope, D. H., Lowery, H. K. (1983). Bacterioplankton in Antarctic Ocean waters during late austral winter: abundance, frequency of dividing cells and estimates of production. Appl. environ. Microbiol. 45 1622-1632

Hauxhurst, J. D., Krichevsky, M. I., Atlas, R. M. (1980). Numerical taxonomy of bacteria from the Gulf of Alaska. J. gen Microbiol. 120: 131-148

Hobbie, J. E., Daley, R. J., Jasper, S. (1977). Use of Nuclepore filters for counting bacteria by fluorescence microscopy A.ppl. environ. Microbiol. 33: 1226-1255

Hodson, R. E., Azam, F., Carlucci, A. F., Fuhrman, J. A., Karl D. M., Holm-Hansen, O. (1981). Microbial uptake of dissolved organic matter in McMurdo Sound, Antarctica. Mar. Biol. 61: 89-94

Hollibaugh, J. T (1988). Limitations of the $\left[{ }^{3} \mathrm{H}\right]$ thymidine method for estimating bacterial productivity due to thymidine metabolism. Mar. Ecol. Prog. Ser. 43: 19-30

Hopkinson, C. S., Jr, Sherr, B., Wiebe, W. J. (1989) Size fractionated metabolism of coastal microbial plankton. Mar. Ecol. Prog. Ser. 51: 155-166

Jassby, A. D., Platt, T. (1976). Mathematical formulation of the relationship between photosynthesis and light for phytoplankton. Limnol. Oceanogr. 21: 540-547

Karl, D. M. (1986). Determination of in situ microbial biomass, viability, metabolism, and growth. In: Poindexter, J. S. Ledbetter, E. R. (eds.) Bacteria in nature, Vol. 2. Plenum Press, New York, p. 85-177

Kirchman, D. L. (1990). Limitation of bacterial growth by dissolved organic matter in the subarctic Pacific. Mar. Ecol. Prog. Ser. 62: 47-54

Kirchman, D. L., Hoch, M. P. (1988). Bacterial production in the Delaware Bay estuary estimated from the thymidine and leucine incorporation rates. Mar. Ecol. Prog. Ser. 45 $169-178$

Kirchman, D. L., K'nees, E., Hodson, R. E. (1985). Leucine incorporation and its potential as a measure of protein synthesis by bacteria in natural aquatic systems. Appl. environ. Microbiol. 49: 599-607 
Leggett, W. C., Frank, K. T., Carscadden, J. C. (1984). Meteorological and hydrographic regulation of year-class strength in capelin (Mallotus villosus). Can. J. Fish. Aquat. Sci. 41: 1193-1201

Li, W. K. K., Dickie, P. M. (1987). Temperature characteristics of photosynthetic and heterotrophic activities: seasonal variations in temperature microbial plankton. Appl. environ. Microbiol. 53: 2282-2295

Linley, E. A. S., Newell, R. C. (1984). Estimates of bacterial growth yields based on plant detritus. Bull. mar. Sci. 35: $409-425$

Lucas, M. I., Painting, S. J., Muir, D. G. (1986). Estimates of carbon flow through bacterioplankton in the $\mathrm{S}$. Benguela upwelling region based on ${ }^{3} \mathrm{H}$-thymidine incorporation and predator-free incubations. Deuxième Colloque International de Bactériologie marine, Actes de Colloques 3: 375-383

Macko, S. A., Green, E. J. (1982) An investigation of the dissolved free amino acids and their relation to phytoplankton in the Damariscotta River estuary. Estuaries 5: $68-73$

McManus, G. B., Peterson, W. T. (1988). Bacterioplankton production in the nearshore zone during upwelling off central Chile. Mar. Ecol. Prog. Ser 43: 11-17

Mopper, K., Lindroth, P. (1982). Diel and depth variations in dissolved free amino acids and ammonium in the Baltic Sea determined by shipboard HPLC analysis. Limnol. Oceanogr. 27: 336-347

Moran, M. A., Hodson, R. E. (1990). Contributions of degrading Spartina alterniflora lignocellulose to the dissolved organic carbon pool of a salt marsh. Mar. Ecol. Prog. Ser. 62: $161-168$

Morita, R. Y., Griffiths, R. P., Hayasaka, S. S. (1977). Heterotrophic activity of micro-organisms in Antarctic waters. In: Llano, G. A. (ed.) Adaptations within Antarctic ecosystems. Smithsonian Institution, Washington, D. C., p. 99-113

Nedwell, D. W. (1989). Benthic microbial activity in an Antarctic coastal sediment at Signy Island, South Orkney Islands. Estuar, coast. Shelf Sci. 28: 1-10

Newell, S. Y., Christian, R. R. (1981). Frequency of dividing cells as an estimator of bacterial productivity. Appl environ. Microbiol. 42: 23-31

Nielsen, T. G., Richardson, K. (1989). Food chain structure of the North Sea plankton communities: seasonal variations of the role of the microbial loop. Mar Ecol. Prog. Ser. 56: $75-87$

Nishino, S. F. (1986). Direct acridine orange counting of bacteria preserved with acidified Lugol iodine. Appl. environ. Microbiol. 52: 602-604

Ostrom, N. E., Macko, S. A. (in press). Sources, cycling and distribution of water column particulate and sedimentary organic matter in northern Newfoundland fjords and bays: a stable isotope study. In: Whalen, J., Farrington, J. (eds). Productivity, accumulation, and preservation of organic matter: recent and ancient sediments. Columbia University Press, New York

Platt, T., Jassby, A. D. (1976). The relationship between photosynthesis and light for natural assemblages of coastal marine phytoplankton. J. Phycol. 12: 421-430

Pollard, P. C., Moriarty, D. J. (1984). Validity of the tritiated thymidine method for estmating bacterial growth rates: measurement of isotope dilution during DNA synthesis. Appl environ. Microbiol. 48: 1076-1083

Pomeroy, L. R., Deibel, D. (1986). Temperature regulation of bacterial activity during the spring bloom in Newfoundland coastal waters. Science 233: 359-361

Pomeroy, L. R., Johannes R. E. (1968). Occurrence and respira- tion of ultraplankton in the upper $500 \mathrm{~m}$ of the ocean. Deep Sea Res. 15: 381-391

Pomeroy, L. R., Wiebe, W. J.(1988). Energetics of microbial food webs. Hydrobiologia 15.9: 7-18

Pomeroy, L. R., Paffenhöfer, G.-A., Yoder, J. A. (1987). Summer upwelling on the southeastern continental shelf of the U.S.A. during 1981. Interactions of phytoplankton, zooplankton and microorganisms. Prog. Oceanogr. 19: 353-372

Pomeroy, L. R., Macko, S. A., Ostrom, P. H., Dunphy, J. (1990). The microbial food web in Arctic seawater: concentration of dissolved free amino acids, bacterial abundance and activity in the Arctic Ocean and in Resolute Passage. Mar. Ecol. Prog. Ser. 61: 31-40

Pomroy, A. J. (1984). Direct counting of bacteria preserved with Lugol iodine solution. Appl. environ. Microbiol. 47 1191-1192

Raj, H. D., Maloy, S. R. (1990a). Family Spirosomaceae: Gramnegative ring-forming aerobic bacteria. Crit. Rev. Microbiol. 17: 329-364

Raj, H. D., Maloy, S. R. (1990b). Proposal of Cyclobacterium marinus gen nov., comb. nov. for a marine bacterium previously assigned to the genus Flectobacillus. Int. J. syst Bacteriol. 40: 337-347

Reichardt, W. T. (1987). Burial of antarctic microalgal debris in bioturbated deep-sea sediments. Deep Sea Res. 34: $1761-1770$

Rowe, G. T., Sibuet, M., Deming, J., Tietjen, J., Khripounoff, A. (1990). Organic carbon turnover time in the deep-sea benthos. Prog. Oceanogr. 24: 141-160

Schell, D. M. (1974). Uptake and regeneration of free amino acids in marine waters of Southeast Alaska. Limnol Oceanogr. 19: 260-270

Schmaljohan, R. (1984). Morphological investigations on bacterioplankton of the Baltic Sea, Kattegat and Skagerrak. Botanica mar 27: 425-436

Schnack, S. B., Smetacek, V., Bodungen, B. V., Stegmann, P. (1985). Utilization of phytoplankton by copepods in Antarctic waters during spring. In: Gray, J. S., Christiansen, M. E. (eds.) Marine biology of the Polar regions and effects of stress on marine organisms. John Wiley \& Sons, Ltd., Chichester, p. 65-81

Sieburth, J. McN. (1975). Microbial seascapes. University Park Press, Baltimore

Simon, M., Azam, F. (1989). Protein content and protein synthesis rates of planktonic marine bacteria. Mar. Ecol. Prog. Ser. 51. 201-213

Smetacek, V., Pollehne, F. (1986). Nutrient cycling in pelagic systems: a reappraisal of the conceptual framework. Ophelia 26: 401-428

Smith, K. L., Baldwin, R. J. (1983). Deep-sea respirometry: insitu techniques. In: Gnaiger, E., Forstner, H. (eds.) Polarographic oxygen sensors. Springer, Heidelberg, p. 298-319

Smith, K. L., Clifford, C. H., Eliason, A. H., Walden, B., Rowe, G. T., Teal, J. M. (1976). A free vehicle for measuring benthic community metabolism. Limnol. Oceanogr. 21: 164-170

Smith, R. E. H., Harrison, W. G., Irwin, B., Platt, T (1986). Metabolism and carbon exchange in microplankton of the Grand Banks (Newfoundland). Mar. Ecol. Prog. Ser 34: 171-183

Smith, R. E. H., Clement, P., Cota, G. F. (1989). Populations dynamics of bacteria in arctic sea ice. Microb. Ecol. 17: $63-76$

Sorokin, Y L. (1978). Decomposition of organic matter and regeneration. In: Kinne, O. (ed.) Marine ecology, Vol. IV, Dynamics. Wiley Interscience, Chichester, p. 501-616

Sullivan, C. W., Cota, G. F., Krempin, D. W., Smith, W O., Jr (1990). Distribution and activity of bacterioplankton in the 
marginal ice zone of the Weddell-Scotia Sea during austral spring. Mar. Ecol. Prog. Ser. 63: 239-252

Taggart, C. F., Leggett, W C. (1987) Wind-forced hydrodynamics and their interaction with larval fish and phytoplankton abundance: a time-series analysis of physicalbiological data. Can. J. Fish. Aquat. Sci. 44: 438-541

Wainright, S. A. (1990). Sediment-to-water fluxes of particulate material and microbes by resuspension and their contribution to the planktonic food web. Mar Ecol. Prog. Ser 62: $271-281$

Wassman, P. (1984). Sedimentation and benthic mineralization of organic detritus in a Norwegian fjord. Mar. Biol. 83: $83-94$

This article was presented by S. Y. Newell, Sapelo Island, Georgia, USA
Wicks, R. J., Robarts, R. D. (1987). The extraction and purification of DNA labelled with [methy]- ${ }^{3} \mathrm{H}$ ]-thymidine in aquatic bacterial production studies. J. Plankton Res. 9 $1159-1166$

Williams, P. J. leB. (1984). Bacterial production in the marine food chain: the emperor's new suit of clothes? In: Fasham, M. J. R. (ed.) Flows of energy and materials in marine ecosystems. Plenum Press, New York, p. 271-299

Wright, R. T., Hobbie, J. E. (1965). The uptake organic solutes from lake water. Limnol. Oceanogr 10: 22-28

Wright, R. T., Hobbie, J. E. (1966). Use of glucose and acetate by bacteria and algae in aquatic ecosystems. Ecology 47 : $447-464$

Manuscript first received: March 15, 1991

Revised version accepted: June 6, 1991 